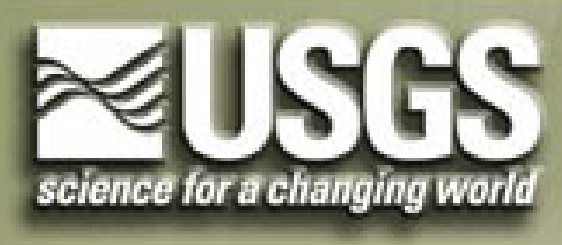

\title{
SURFACE WATER QUALITYASSURANCE PLAN FOR THE SOUTH CAROLINA DISTRICT OF HAE U.S. GEOLOGICAL SURVEY
}

\section{OpentFle Report 01-121}

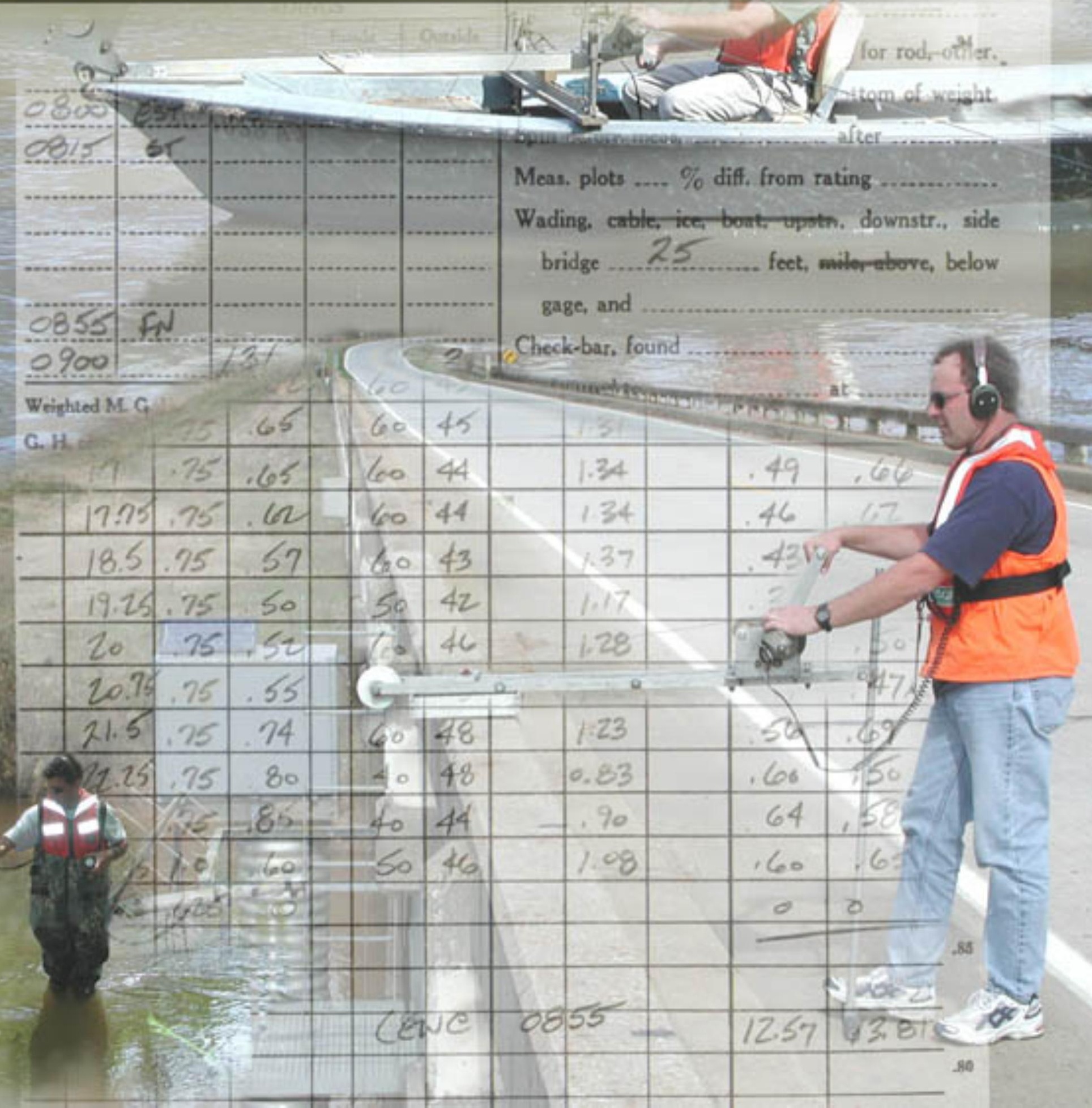




\section{SURFACE WATER QUALITY-ASSURANCE PLAN FOR THE SOUTH CAROLINA DISTRICT OF THE U.S. GEOLOGICAL SURVEY}

By T.W. Cooney

U.S. Geological Survey

Open-File Report 01-121 


\title{
U.S. DEPARTMENT OF THE INTERIOR GALE A. NORTON, Secretary
}

\author{
U.S. GEOLOGICAL SURVEY \\ Charles G. Groat, Director
}

Use of trade, product, or firm names in this publication is for descriptive purposes only and does not imply endorsement by the U.S. Geological Survey.

For additional information

write to:

District Chief

U.S. Geological Survey

720 Gracern Road, Suite 129

Columbia, SC 29210-7651
Copies of this report can be purchased from:

U.S. Geological Survey

Branch of Information Services

Box 25286

Denver, CO 80225

888-ASK-USGS

Additional information about water resources in South Carolina is available on the World Wide Web at http://sc.water.usgs.gov 


\section{CONTENTS}

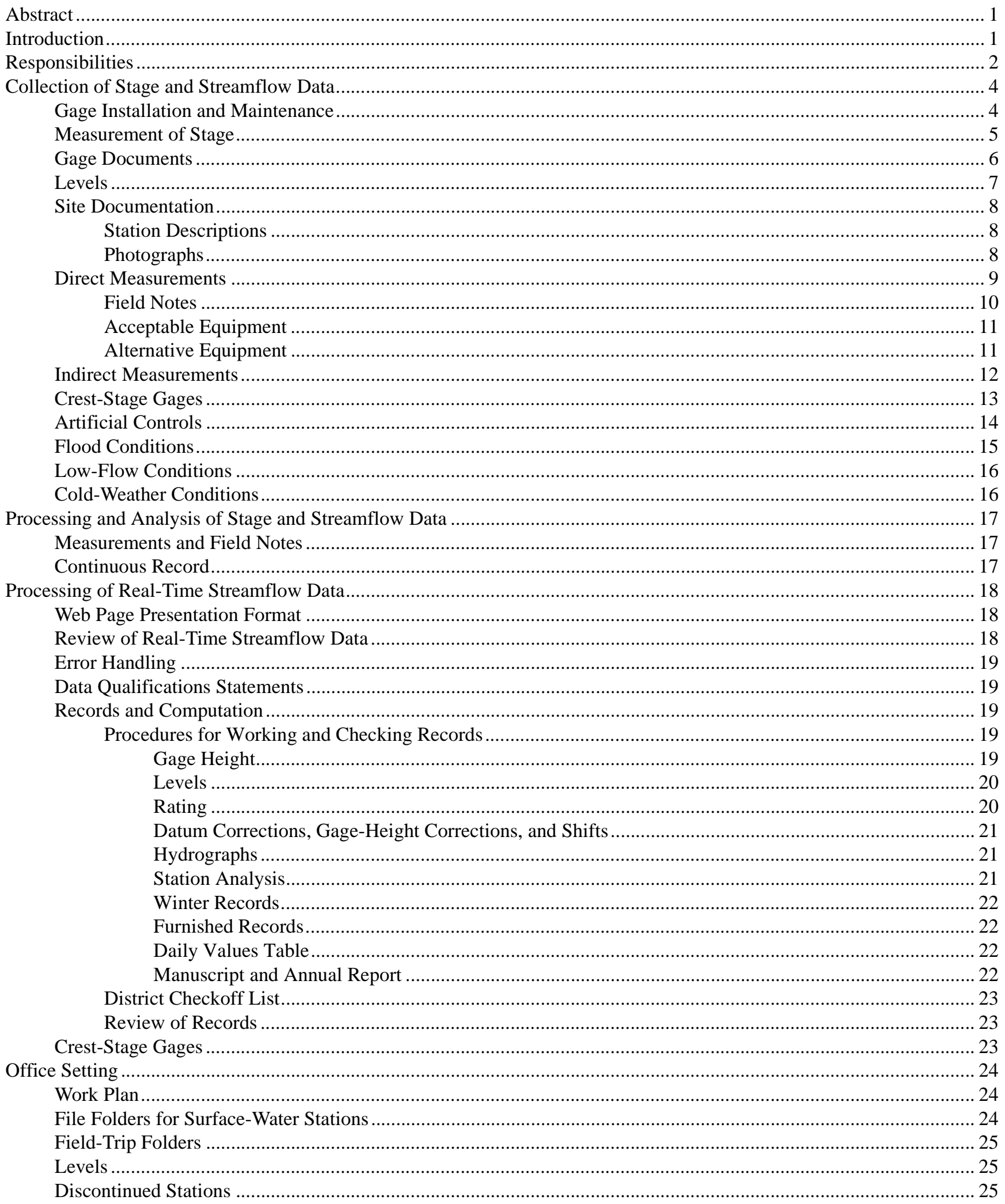




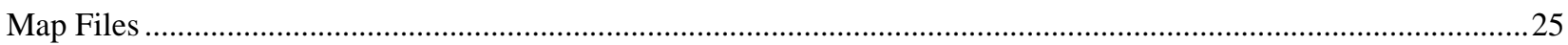

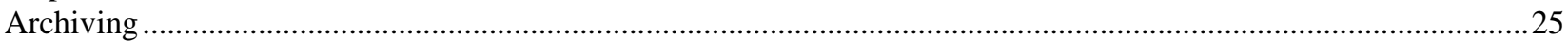

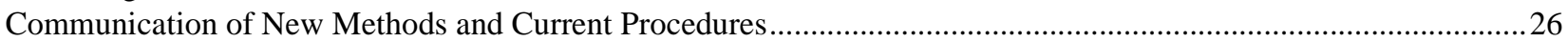

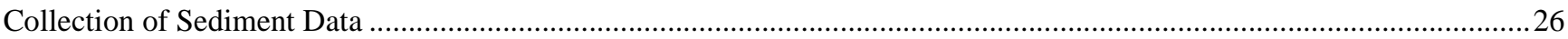

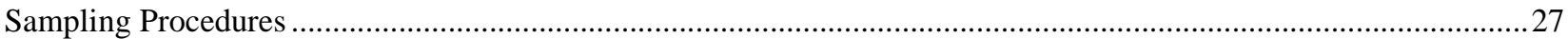

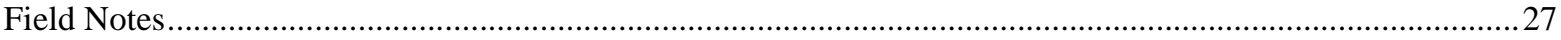

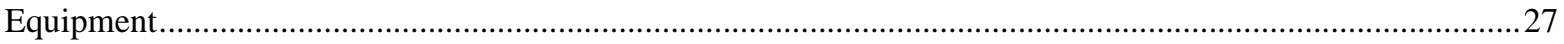

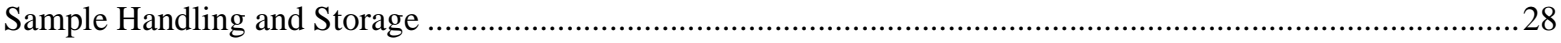

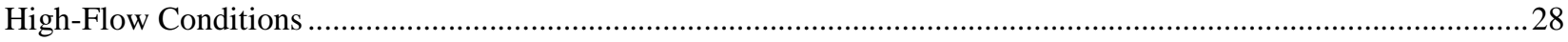

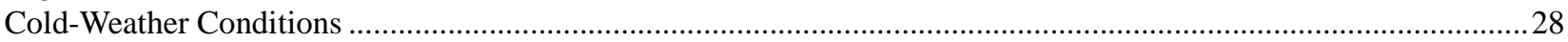

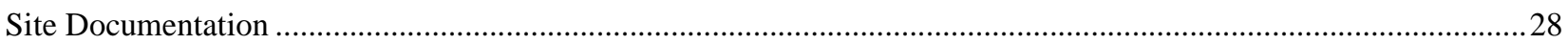

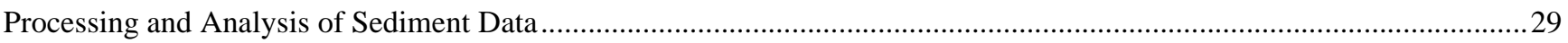

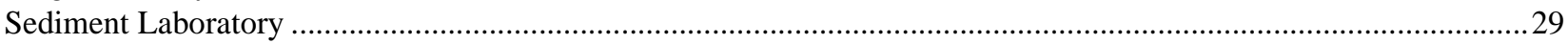

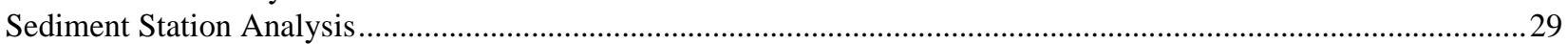

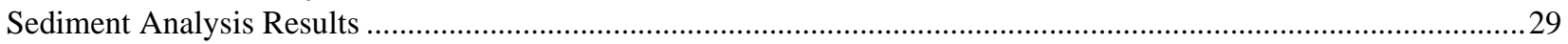

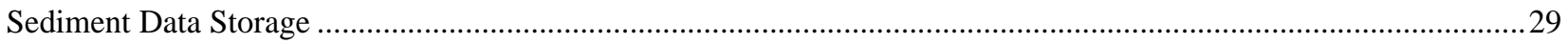

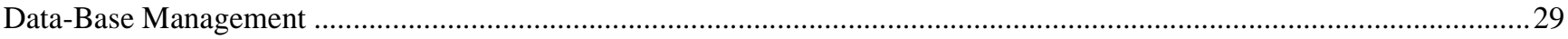

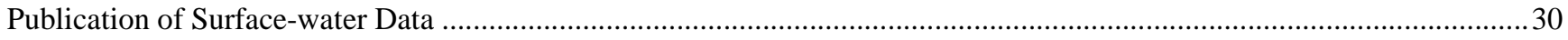

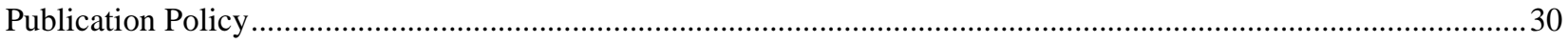

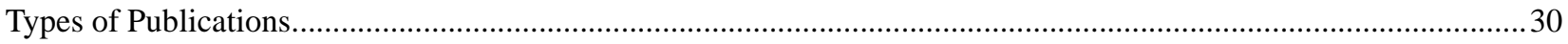

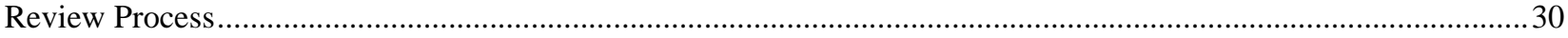

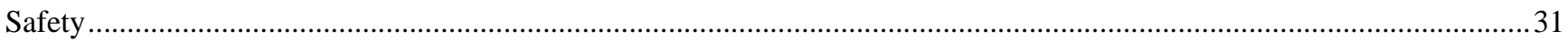

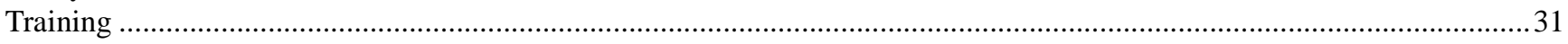

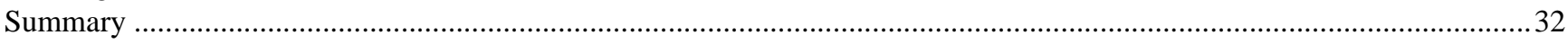

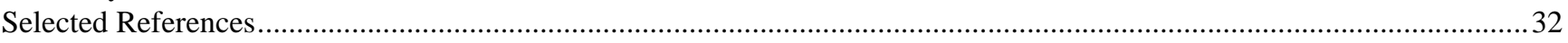

Appendixes

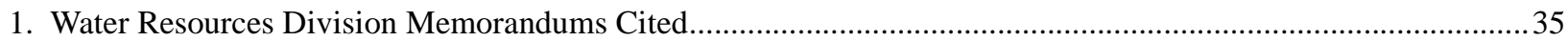

2. Gaging Station Inspection Form for Field-Trip Reviews ....................................................................... 36

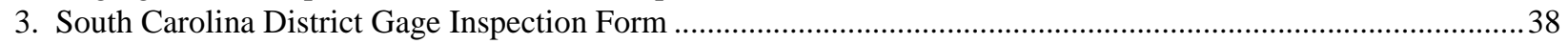

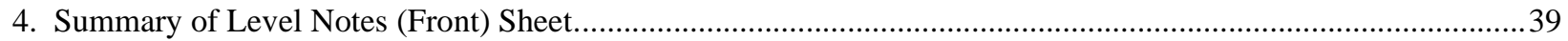

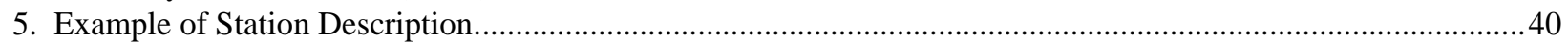

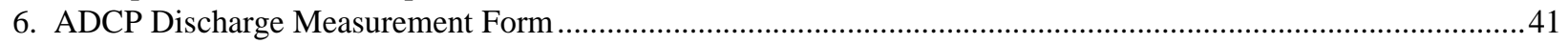

7. Instructions for Completing Discharge Measurement Notes ..................................................................... $42-43$

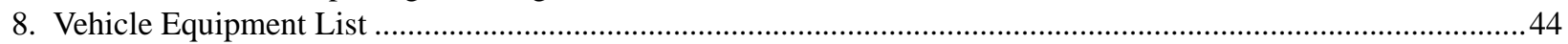

9. South Carolina District Crest-Stage Gage Inspection Form............................................................................ 45

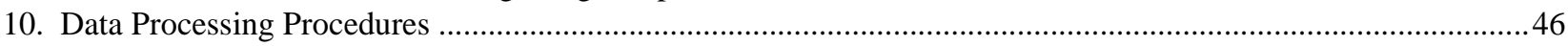

11. Instructions for Generating Final Daily Discharge Table …….......................................................................4

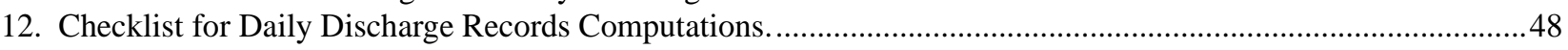

\begin{tabular}{|r|lrl}
\multicolumn{5}{c}{ Abbreviations } \\
\hline & & \\
ADAPS & Automated Data Processing System & OSW & Office of Surface Water \\
ADCP & Acoustic Doppler Current Profiler & QA & Quality Assurance \\
BDR & Basic Data Recorders & SEWI & Single equal width increment method \\
DCP & Data Collection platforms & TWRI & Techniques of Water-Resources Investigations \\
EWI & Equal Width Increment method & USGS & U.S. Geological Survey \\
FRC & Federal Records Center & UWI & Unequal Width Increment method \\
MEWI & Multiple Equal Width Increment method & WRD & Water Resources Division \\
NAWQA & National Water Quality Assessment Program & WSC & Water Survey of Canada \\
NWIS & National Water Information System & WSPRO & Water-Surface Profile Computation model \\
& & &
\end{tabular}




\title{
Surface Water Quality-Assurance Plan for the South Carolina District of the U.S. Geological Survey
}

\author{
By T.W. Cooney
}

\begin{abstract}
This District Surface Water Quality-Assurance Plan documents the standards, policies, and procedures used by the South Carolina District for activities related to the collection, processing, storage, analysis, and publication of surface-water data.
\end{abstract}

\section{INTRODUCTION}

The U.S. Geological Survey (USGS) was established by an act of Congress on March 3, 1879, to provide a permanent Federal agency to perform the systematic and scientific "classification of the public lands, and examination of the geologic structure, mineral resources, and products of the national domain." Surface-water activities in the South Carolina District are part of the Water Resources Division's (WRD) overall mission of appraising the Nation's water resources. Surface-water information, including streamflow, stage, and sediment data, are used at the Federal, State, and local levels for resources planning and management.

The purpose of this District Surface-Water Quality-Assurance Plan (QA Plan) is to document the standards, policies, and procedures used by the South Carolina District for activities related to the collection, processing, storage, analysis, and publication of surface-water data.

This plan identifies responsibilities for ensuring that stated policies and procedures are carried out. The plan also serves as a guide for all District personnel involved in surface-water activities and as a resource for identifying memorandums, publications, and other literature that describe in more detail associated techniques and requirements.

The scope of this report includes discussions of the policies and procedures followed by this District for the collection, processing, analysis, storage, and publication of surface-water data. Specific types of surface-water data include stage, streamflow, sediment, and basin characteristics. In addition, issues related to the management of the computer data base, and employee safety and training are presented. Although procedures and products of interpretive projects are subject to the criteria presented in this report, specific interpretive projects are required to have a separate and complete quality-assurance plan. 
This QA Plan is reviewed and revised at least once every 3 years in order that responsibilities and methodologies are kept current and that the ongoing procedural improvements can be effectively documented.

\section{RESPONSIBILITIES}

Quality assurance (QA) is an active process. Achieving and maintaining high-quality standards for surfacewater data are accomplished by specific actions carried out by specific persons. Errors and deficiencies can result when individuals fail to carry out their responsibilities. Clear and specific statements of responsibilities promote an understanding of each person's duties in the overall process of assuring surface-water data quality.

The following is a list of responsibilities of District personnel involved in the collection, processing, storage, analysis, or publication of surface-water data.

The District Chief is responsible for:

1. Managing and directing the District program, including all surface-water activities.

2. Ensuring that surface-water activities in the District meet the needs of the Federal Government, the South Carolina District, State and local agencies, other cooperating agencies, and the general public.

3. Ensuring that all aspects of this QA Plan are understood and followed by District personnel. This is accomplished by the District Chief's direct involvement or through clearly stated delegation of this responsibility to other personnel in the District.

4. Providing final resolution of any conflicts or disputes related to surface-water activities within the District.

5. Keeping subordinates briefed on procedural and technical communications from Regional Offices and Headquarters.

6. Performing technical reviews of all surface-water programs on a semiannual basis.

7. Ensuring that all publications and other technical communications released by the District are accurate and are in accord with USGS policy.

The Assistant District Chief (Chief, Hydrologic Data Surveillance and Analysis Section), hereinafter referred to as Data Chief, is responsible for:

1. Ensuring that all aspects of the QA Plan are understood and followed by all personnel in the Hydrologic Data Surveillance and Analysis Unit and the New Ellenton, Conway, Sullivan's Island, and Clemson Field Offices.

2. Updating the QA Plan at least every 3 years. Updates and revisions will be documented and distributed by memorandum to all South Carolina District personnel after approval by the Surface-Water Specialist and District Chief.

3. Ensuring that the Annual Data Report is published by the established deadline and all data published are collected, processed, and stored in accord with USGS policy.

4. Serving as the District flood coordinator.

5. Identifies training needs for personnel in the Hydrologic Data Surveillance and Analysis Section, with feedback from Field Office Chiefs.

The Assistant District Chief (Chief, Hydrologic Investigations Section), hereinafter referred to as Project Section Chief, is responsible for:

1. Ensuring that all aspects of the QA Plan are understood and followed by all personnel in the Hydrologic Investigations Section.

2. Performing technical reviews of surface-water projects in the Hydrologic Investigations Section on a semi-annual basis. 
1. Approving updates and revisions to the QA Plan as necessary.

2. Performing technical reviews of all surface-water projects on a semiannual basis.

3. Developing and ensuring that District surface-water project proposals are in accord with USGS policy.

4. Providing assistance and training to District personnel on surface-water activities.

The Columbia Field Office Chief is responsible for:

1. Ensuring that all aspects of the QA Plan are understood and followed by all field personnel in the Columbia and Clemson Field Offices.

2. Serving as the alternate District flood coordinator.

3. Reviewing real-time data on a daily basis for quality control purposes.

The Conway Field Office Chief is responsible for:

1. Ensuring that all aspects of the QA Plan are understood and followed by all personnel in the Conway and Sullivans Island Field Offices.

2. Serving as the District contact for all Acoustic Doppler Current Profiler (ADCP) activities and maintaining QA files for the ADCP, as mandated by the Office of Surface Water (OSW).

The New Ellenton Field Office Chief is responsible for:

1. Ensuring that all aspects of the QA Plan are understood and followed by all personnel in the New Ellenton Field Office.

2. Reviewing real-time data on a daily basis for quality control purposes.

The District Computer Specialist is responsible for:

1. Performing the necessary routine maintenance and updates to ensure efficient processing of surface-water data.

2. Providing data to cooperators using District retrieval programs and to the Internet in an efficient and timely manner.

3. Ensuring that historical data are archived using standard computer techniques and following USGS policy as detailed in WRD Memorandum 99.33.

The District Safety Officer is responsible for:

1. Ensuring that all District personnel are kept informed of safety issues related to surface-water activities, and preparing any necessary District safety plans. 


\section{COLLECTION OF STAGE AND STREAMFLOW DATA}

Many of society's daily activities, including industry, agriculture, energy production, waste disposal, and recreation, are closely linked to streamflow and water availability; therefore, reliable surface-water data are necessary for planning and resource management. The collection of stage and streamflow data is a primary component in the ongoing operation of streamflow-gaging stations (referred to in the remainder of this report as gaging stations) and other water-resource studies performed by the USGS and the South Carolina District.

The objective of operating a gaging station is to obtain a continuous record of stage and discharge at the site (Carter and Davidian, 1968, p. 1). A continuous record of stage is obtained by installing instruments that sense and record water-surface elevation in the stream. Discharge measurements are made at periodic intervals to define or verify the stage-discharge relation and to define the time and magnitude of variations in that relation.

It is the policy of this District that all personnel involved in the collection of stage and discharge data are informed of and follow the surface-water data-collection policies and procedures established by WRD.

\section{Gage Installation and Maintenance}

Proper installation and maintenance of gaging stations are critical activities for ensuring quality in streamflow- data collection and analysis. Effective site selection, correct design and construction, and regular maintenance of a gage can make the difference between efficient and accurate determination of drainage-basin discharge or time-consuming, poor estimations of flow.

Sites for installation of gaging stations are selected with the intent to meet the purpose of each specific gage. Additionally, sites are selected with the intent of achieving, to the greatest extent possible, ideal hydraulic conditions. Criteria that describe the ideal gaging-station site are listed in Rantz and others (1982, p. 5). These criteria include unchanging natural controls that promote a stable stage-discharge relation, a satisfactory reach for measuring discharge throughout the range of stage, and the means for efficient access to the gage and measuring location. Other aspects of controls considered by District personnel when planning gage-house installations include those discussed in Kennedy (1984, p. 2).

The individual responsible for selecting sites for new gaging stations is the Data Chief or selected designee. The process of site selection includes a discussion with cooperators on the purpose of the gage, field reconnaissance to evaluate gaging conditions, and submittal of encroachment permits, if necessary. The responsibility for ensuring proper documentation of agreements with property owners is held by the Data Chief. Approval of site design is the responsibility of the District Safety Officer and Data Chief, or their designees. Responsibility for construction of gages is held by the appropriate Field Office Chief. Inspection and approval of the completed installation is the responsibility of the District Safety Officer and Data Chief, or their designees.

A program of careful inspection and maintenance of gages and gage houses promotes the collection of reliable and accurate data. Allowing the equipment and structures to fall into disrepair can result in unreliable data and safety problems. It is District policy that a visual inspection is performed at sites by field personnel during each site visit and a safety inspection form completed once each year. To prevent the buildup of mud or the clogging of intakes, concrete stilling wells are pumped and intakes are flushed on an annual basis. Stilling wells located in the stream are equipped with clean-out doors and are cleaned during each site visit, if accessible by wading. Wells accessible by boat only are cleaned at least annually, as conditions permit. Other maintenance activities performed on a regular basis include checking battery voltage, inspecting wiring and connections, cleaning solar panels, and general housekeeping. 
It is the responsibility of all field personnel to ensure that their gages and gage houses are kept in good repair, functional, and outside gages are legible. To ensure these responsibilities are carried out, each field trip is reviewed on an annual basis by inspecting at least three gages on each field trip. Gages are inspected by the Data Chief, Field Office Chiefs or designated personnel experienced in surface-water data collection using the "Gaging Station Inspection Form" shown in Appendix 2. Inspection assignments are made by the Data Chief and copies of each inspection are provided to the Data Chief, Field Office Chief, and responsible field personnel. Each Field Office Chief is responsible for ensuring that deficiencies are corrected.

\section{Measurement of Stage}

Many types of instruments are available for measuring the water level, or stage, at gaging stations. There are nonrecording gages (Rantz and others, 1982, p. 24) and recording gages (Rantz and others, 1982, p. 32). Because the uses to which stage data may be utilized cannot be predicted, it is OSW policy that surface-water stage records at stream sites be collected with instruments and procedures that provide sufficient accuracy to support computation of discharge from a stage-discharge relation, unless greater accuracy is required (Office of Surface Water Memorandum 93.07).

In general, operation of gaging stations for the purpose of determining daily discharge includes the goal of collecting stage data at the accuracy of + or -0.01 foot (Office of Surface Water Memorandum 89.08). An explanation of WRD policy on stage-measurement accuracy as it relates to instrumentation is provided in Office of Surface Water Memorandum 93.07.

The types of instrumentation installed at any specific gage house operated by the South Carolina District is dependent on the needs of the cooperator, the expected range of stage, and type of stilling well. Types of waterlevel recorders operated by personnel in this District include Data Collection Platforms (DCP), Basic Data Recorders (BDR), and various pressure sensors.

The responsibility for determining what type of water-level recorders are operated at each gaging station is held by the Data Chief or his designee. Recorders are programmed to collect stage at 15-minute intervals, except for certain gages with large drainage areas, and all lake/reservoir gages, which collect stage at 60-minute intervals. Ensuring that new equipment has been installed correctly is the responsibility of the field technician and appropriate Field Office Chief. Proper maintenance of gage instrumentation or replacement, if appropriate, of equipment is the responsibility of the field technician who services the gage routinely as part of their field-trip.

Accurate stage measurement requires not only accurate instrumentation but also proper installation and continual monitoring of all system components to ensure the accuracy does not deteriorate with time (Office of Surface Water Memorandum 93.07). To ensure that instruments, located within the gage house, record water levels that accurately represent the water levels of the body of water being investigated, "inside" and "outside" waterlevel readings are obtained by independent means and are compared to the designated reference gage, as described in the station description and/or station analysis. For example, station 02169500 (Congaree River at Columbia, S.C.) uses a tape-down point as the inside reference gage (a float-tape gage and staff section act as auxiliary inside gages) and a series of staff sections provide outside gage readings. The inside gage readings do not necessarily always equal outside readings, especially if the gages are not in the same pool at all ranges of stage. At stations equipped with a stilling well, the base or reference gage usually is an instrument installed inside the gage house, and other gages are installed outside the gage house to indicate whether or not the intakes are operating properly (Rantz and others, 1982, p. 53 and 64). 
Personnel servicing the gage are responsible for comparing inside and outside readings during each site visit to determine if the outside water level is being represented correctly by the gages. If a deficiency is identified, the personnel servicing the gage are responsible for thoroughly documenting the problem on the field note sheet and either correcting the problem immediately or contacting their immediate supervisor so that corrective actions can be taken at the earliest opportunity.

Ensuring that instrumentation installed at gaging stations is properly serviced and calibrated is the responsibility of the Field Office Chiefs. This responsibility is accomplished by reviewing data at all satellite telemetry gages daily. When deficiencies are identified, the field technician responsible for the gage makes a site visit with spare equipment to repair or replace instrumentation. Gages with DCP's and BDR's will have BDR data downloaded prior to departure. Individuals who have questions related to the calibration and maintenance of water-level recorders should contact the appropriate Field Office Chief (refer to Office of Surface Water Memorandum 91.09).

All gage inspections are documented using the South Carolina District form shown in Appendix 3, unless a discharge measurement is made. Documentation includes equipment identification numbers, maximum and minimum stage indicators, and gage readings on arrival and departure. In general, continuous recorders are reset if the reading differs more than 0.02 foot from the base gage.

Most of the basic concepts and procedures used in surface-water data collection activities are presented in the three "Techniques of Water-Resources Investigations" (TWRI) of the U.S. Geological Survey series chapters entitled "General Procedures for Gaging Streams," "Stage Measurements at Gaging Stations," and "Discharge Measurements at Gaging Stations." A number of the important aspects contained in these references are enumerated and reinforced here. Generally, all surface-water data collection activities are in accordance with procedures as outlined in the TWRI's. For data collection activities not adequately covered by written instruction, supervisors only assign personnel who are capable through unique experience and/or special training.

On-the-job training of new employees in standard, acceptable field practices is performed by designees of the Data-Section Chief. In all cases, instructors are experienced and knowledgeable concerning prescribed techniques and proper procedures. Data collected by inexperienced field personnel are closely examined for completeness, accuracy and adherence to prescribed collection techniques by the appropriate Field Office Chief or designated members of the Hydrologic Data Unit. The intensity of the examinations remains at a high level until such time as the employee possesses a thorough knowledge of technical concepts and demonstrates acceptable practical skills.

To ensure that personnel are knowledgeable concerning currently prescribed practices, procedures, and methodologies, and that existing guidelines are followed, the District Training Officer and Discipline Specialist in cooperation with appropriate section chiefs, project leaders and individuals, identify training needs and conduct, direct, or arrange formal technical training sessions. Formal training needs are addressed in each individual's training plan. These plans are updated at least once a year along with other aspects of individual career development plans. Updates are made as required by training received, reassignment, or project activities changes.

\section{Gage Documents}

It is District policy that certain documents are placed in each gage house for the purpose of keeping an onsite record of observations, equipment maintenance, structural maintenance, and other information helpful to field personnel. Documents maintained at each gage house include: (1) the most recent digital stage-discharge 
relation (rating); (2) a graph of the rating upon which each new measurement is plotted; (3) the most recent station description listing all gages and reference marks at the site and associated elevations, locations of measurement cross sections, information related to extreme events including the potential for channel storage between the gage and measuring section during flood conditions, and other information (see the section "Site Documentation, Station Description" in this report); (4) a log updated by field personnel upon each site visit describing control conditions and listing gage readings, measurement values, gage-house maintenance, and equipment maintenance; (5) a calendar; and (6) a copy of the current DCP/BDR program.

It is the responsibility of field personnel to exchange outdated material with updated gage documents as needed. When field personnel visit a gage house and identify a need to update one or more of the documents, a list of document needs should be added to the inspection notes. These documents are provided by Field Office Chiefs. Individuals having questions related to what documents should be kept in a gage house, when the documents should be replaced with newer documents, or appropriate methods of appending logs or plotting measurements should contact the Field Office Chief or Data Chief.

\section{Levels}

The various gages at a gaging station are set to register the altitude of a water surface above a selected level reference surface called the gage datum. The gage's supporting structures--stilling wells, backings, shelters, bridges, and other structures--tend to settle or rise as a result of earth movement, static or dynamic loads, vibration, or battering by floodwaters and flood-borne ice or debris. Vertical movement of a structure makes the attached gages read too high or too low and, if the errors go undetected, may lead to increased uncertainties in streamflow records. Leveling, a procedure by which surveying instruments are used to determine the differences in altitude between points, is used to set the gages and to check them from time to time for vertical movement (Kennedy, 1990, p. 1). Levels are run periodically to all bench marks, reference marks, reference points, and gages at each station for the purpose of determining if any datum changes have occurred (Rantz and others, 1982, p. 545).

It is District policy that levels are run at newly installed gaging stations at the time of construction and installation of recording devices. Levels are run to established gaging stations every 3 years or when discrepancies between inside and outside gages are observed and must be documented. Gages are reset to agree with levels when: (1) math is checked on level notes; (2) closure is acceptable; and (3) water-surface elevations are obtained in the gage pool. Inside reference gages, including the base gage, are reset if they are in error by more than $0.02 \mathrm{ft}$. Outside gages are reset if they are more than $0.02 \mathrm{ft}$. in error. When gages are reset, field personnel document the reset by stating clearly on the level note sheet the changes that were made and all gage readings at time of departure (add miscellaneous note sheets as necessary). Standard form 9-275 is used for level notes at gaging stations. The standard South Carolina District Summary Sheet, is shown in Appendix 4, and is completed by the instrument man and attached as the front sheet prior to filing. Level notes must identify the instrument used to complete the station levels and the date that the instrument was last peg-tested. Identification consists of the make of the instrument used and the serial number or property (W) number. A copy of the last peg-test is kept in the instrument case for reference.

Levels are run by use of field methods and documentation methods described in Kennedy (1990). Level procedures followed by District personnel pertaining to circuit closure, instrument reset, and repeated use of turning points are described in Kennedy (1990) and in Office of Surface Water Memorandum 93.12. The level instruments are kept in proper adjustment by the peg test described in Kennedy (1990, p. 13). Peg tests on 
instruments used by Columbia Field Office personnel are completed on a monthly basis and the documentation maintained by the Columbia Field Office Chief. Peg tests on instruments used by the Conway and New Ellenton Field Offices are completed at least semiannually and documentation maintained by the Field Office Chief.

It is the responsibility of each Field Office Chief to ensure that all field level notes are checked. The level information is entered in the level-summary form by personnel working the annual record for publication purposes. Ensuring that levels are run correctly and that all level notes are completed correctly is the responsibility of each Field Office Chief. Ensuring that levels are run at the appropriate frequency is the responsibility of the Data Chief.

\section{Site Documentation}

Thorough documentation of qualitative and quantitative information describing each gaging station is required. This documentation, in the form of a station description and photographs, provides a permanent record of site characteristics, structures, equipment, instrumentation, altitudes, location, and changes in conditions at each site. Information pertaining to where these forms of documentation are maintained is discussed in the section of this report entitled "Office Setting."

\section{Station Descriptions}

A station description is prepared for each gaging station and becomes part of the permanent record for each station. A hard copy of the first station description, as well as all updated versions, is maintained in the general folder in the backfiles. It is District policy that the station description is written as soon as possible, but no later than when the first year's records are computed. The responsibility for ensuring that station descriptions are prepared correctly and in a timely manner is held by the responsible field personnel with assistance from Field Office Chiefs and Data Chief. Hard copies of the station descriptions are updated as needed and maintained in the current folder. It is the responsibility of the Field Offices Chiefs to ensure that station descriptions are updated as described. Station descriptions are reviewed and the electronic file is edited by Field Office Chiefs during routine processing of records for publication.

Station descriptions are written to include specific types of information in a consistent format (Kennedy, 1983, p. 2). An example station description is shown in Appendix 5. Descriptions for stations not located on major highways must include a road log for locating the gage. An electronic version of each current station description is maintained on the SUN system in the directory "archives/sta.desc". Non-routine updates are made as needed by Field Office Chiefs or their designee. Station numbers are assigned and location maps are maintained by the Data Chief or a designee.

\section{Photographs}

Photographs of newly installed gage houses, station controls, reference marks, damaged structures, or measuring sections, are made by field personnel for the purpose of documenting gage-house construction, changes in control conditions, or to supplement various forms of written descriptions. Each photograph that becomes part of the station record is identified by writing specific types of information (including date) on the back of the photograph with a permanent-ink marker. Photographs for the current year are placed in the current folder, and older photographs are placed in the general folder. 


\section{Direct Measurements}

Direct measurements of discharge are made with any one of a number of methods approved by WRD. The most common is the current-meter method.

A current-meter measurement is the summation of the products of the subsection areas of the stream cross section and their respective average velocities (Rantz and others, 1982, p. 80). Procedures used for current-meter measurements are described in Carter and Davidian (1968, p. 7), Buchanan and Somers (1969, p. 1) and Rantz and others (1982, p. 139).

When personnel make measurements of stream discharge, attempts are made to minimize errors. Sources of errors are identified in Sauer and Meyer (1992). These include random errors such as depth errors associated with soft, uneven, or mobile streambeds, or uncertainties in mean velocity associated with vertical-velocity distribution errors and pulsation errors. These errors also include systematic errors, or bias, associated with improperly calibrated equipment or the improper use of such equipment. In order to minimize systematic errors, field-trips are rotated every 2 years. In addition, Field Office Chiefs accompany field personnel on field-trips at least annually, and as assigned by the Data Chief.

District policies related to the measurement of discharge by use of the current-meter method, in accordance with WRD policies, include the following:

Depth criteria for meter selection.--District personnel select the type of current meter to be used for each discharge measurement on the basis of criteria provided by the OSW (written commun., 1995), Meters are used with caution when a measurement must be made in conditions outside of the ranges of the method provided by OSW. Any deviation from those criteria are noted and the measurement accuracy is downgraded accordingly.

It is recommended that a change of meters is made during a measurement in response to the occurrence of five or more subsections in a single measurement cross section that exceed the stated ranges of depth and velocity. However, some flood plains and shallow overflow channels will require a change in meters if the shallow areas represent more than 15 percent of the total discharge.

Number of measurement subsections.--The spacing of observation verticals in the measurement section can affect the accuracy of the measurement (Rantz and others, 1982, p. 179). The WRD criteria are that observations of depth and velocity be made at a minimum of about 30 verticals, which are normally necessary so that no more than 5 percent of the total flow is measured in any one vertical. Even under the worst conditions the discharge computed for each vertical should not exceed 10 percent of the total discharge and ideally not exceed more than 5 percent (Rantz and others, 1982, p. 140). Exceptions to this policy are allowed in circumstances where accuracy would be sacrificed if this number of verticals were maintained, such as for measurements during rapidly changing stage (Rantz and others, 1982, p. 174). Fewer verticals than are ideal are sometimes used for very narrow streams (about 12-feet wide when an AA meter is used and about 5 feet wide when a pygmy meter is used). Measurement of discharge is essentially a sampling process, and the accuracy of sampling results typically decreases markedly when the number of samples is less than about 25 .

Other direct methods of measuring discharge.--It is District policy that WRD and OSW techniques and guidelines are followed when discharge measurements are made with any selected method of measurement. These methods include measurements made with the Acoustic Doppler Current Profiler (ADCP), flumes, or by volumetric methods. The accuracy of the ADCP is verified at least annually by comparison with conventional current-meter measurements. If the ADCP and current-meter measurements do not agree within 5 percent, the 
Data Chief is notified and remedial action taken. Flume equations and volumetric conversions are checked by the appropriate Field Office Chief. Five separate volumetric measurements are averaged and used as the measurement discharge.

Computation of mean gage height.--District personnel use procedures for the computation of mean gage height during a discharge measurement presented in Rantz and others (1982, p. 170). Mean gage height is one of the coordinates used in describing the stage-discharge relation at a streamflow-gaging site.

Check measurements.--A second discharge measurement is made for the purpose of checking a first discharge measurement when the first discharge does not agree with the stage-discharge relation within 15 percent and similar shifts have not been documented by previous measurements. Any observed changes in the control must be noted and the second discharge measurement made by (1) changing stopwatches or at least verifying accuracy against an independent watch, (2) changing meters (if spare meter is not available, thoroughly inspect the meter and spin test), and (3) altering sectioning.

Corrections for storage.--Corrections for storage applied to measured discharges for the purpose of defining stage-discharge relations are those discussed in Rantz and others (1982, p. 177) and in Office of Surface Water Memorandum 92.09.

Questions.--Personnel who have questions concerning the appropriate procedures for making stage and discharge measurements should address their questions to the appropriate Field Office Chief, Data Chief, or Surface-Water Specialist.

\section{Field Notes}

Thorough documentation of field observations and data-collection activities performed by field personnel is a necessary component of surface-water data collection and analysis. To ensure that clear, thorough, and systematic notations are made during field observations, discharge measurements are recorded by field personnel on standard forms 9-275-F or 9-275-G. ADCP measurements are documented using the form shown in Appendix 6. Original observations, once written on the note sheet, are not erased. Original data are corrected by crossing the value out then writing the correct value. Some examples of original data on a discharge measurement note sheet include gage readings, depth, and velocity observations. Examples of information on a discharge-measurement note sheet that is derived from original data, but not in itself original data, include total area, total discharge, mean gage height, and any additional information not actually observed in the field. Derived data can be erased for the purpose of correction. Instructions for completing the front sheet of standard discharge measurement notes are shown in Appendix 7.

It is District policy that all discharge measurements are calculated in the field and all gage house and field folder documentation completed prior to departing the field site. Information required to be included by field personnel on the measurement note sheet includes, at minimum, the initials and last name of all field-party members, date, times associated with gage readings, control conditions, spin tests (before and after), meter number, and measurement rating. The following guidelines are used for current-meter measurement rating purposes:

"Good" .....No sections $>10 \%$ total Q and mean velocity $>0.50 \mathrm{ft} / \mathrm{s}$, and no angle coefficients $<0.90$;

"Fair" ........1-2 sections $>10 \%$ total Q or mean velocity $<0.50 \mathrm{ft} / \mathrm{s}$, or angle coefficients $<0.90$ and $>0.80$; and

"Poor".......3 or more sections $>10 \%$ total Q or mean velocity $<0.20 \mathrm{ft} / \mathrm{s}$, or angle coefficients $<0.80$. 
Notations associated with miscellaneous surface-water data-collection activities are to be documented on the forms indicated in the "Gage Height" section. All miscellaneous notes are required to include, at minimum, initials and last name of field-party members, date, time associated with observations, purpose of the site visit, and equipment identification numbers.

A review of field note sheets is required after each field trip for personnel with less than 1 year field experience and annually during field trip reviews for experienced personnel. Field trips are reviewed by Field Office Chiefs and other senior personnel designated by the Data Chief. Deficiencies found in the content, accuracy, clarity, or thoroughness of field notes are identified and communicated to the field person, appropriate Field Office Chief, and Data Chief by electronic (e-mail) means. The deficiencies are remedied by providing specific instructions from the Field Office Chief to individuals who fail to record notations that meet USGS and District standards.

\section{Acceptable Equipment}

Equipment used by the South Carolina District for the measurement of surface-water discharge has been found acceptable by the WRD through use and testing. An array of acceptable equipment for measuring discharge includes current meters, timers, wading rods, bridge cranes, tag lines, and others (Smoot and Novak, 1968; and Rantz and others, 1982, p. 82). Although an official list of acceptable equipment is not available, Carter and Davidian (1968), Buchanan and Somers (1969), and Edwards and Glysson (1988) discuss the equipment used by the U.S. Geological Survey.

The meters most commonly used by District personnel for measuring surface-water discharge are the Price AA current meter and the Price pygmy current meter. Methods followed by District personnel for inspecting, repairing, and cleaning these meters are described in Smoot and Novak (1968, p. 9), Buchanan and Somers (1969, p. 7), and Rantz and others (1982, p. 93). Meters are cleaned after every field trip, after use in saltwater, and additional conditions described in Office of Surface Water Memorandum 99.06.

The ultimate responsibility for the good condition and accuracy of a current meter rests with field personnel who uses it (Office of Surface Water Memorandum 89.07). A timed spin test made a few minutes before a measurement does not ensure that the meter will not become damaged or fouled during the measurement. Field personnel must assess apparent changes in velocity or visually inspect the meter periodically during the measurement to ensure that the meter continues to remain in proper operating condition.

Spin tests.--It is District policy that spin tests are required before and after each discharge measurement and prior to each field trip. Spin-test results prior to each field trip are documented in a log that is maintained for each instrument. The spin test prior to each field trip is completed by someone other than the user, if possible. The log is maintained and located in each Field Office. The log for the Columbia Field Office is located in the backfile room. This log is part of the archived data of WRD (Office of Surface Water Memorandum 89.07). Repairs are made to meters when deficiencies are identified through the spin test or inspection. Review of this log by each Field Office Chief is required semiannually. If deficiencies are observed during this review of the log, the Data Chief is informed through written communication and the problem is corrected immediately. The log at each Field Office is reviewed on an annual basis by the Data Chief. To ensure that field personnel carry out their responsibilities in maintaining the equipment they use, the equipment is inspected annually during field-trip reviews. Worn pivots are returned to the Field Office Chief for resurfacing by the HIF, and new or resurfaced pivots are provided as replacements. Meters used in saltwater environments are thoroughly cleaned as soon as possible after each exposure. 


\section{Alternative Equipment}

New conditions and the development of new technology sometimes involve the collection of surface-water data with alternative equipment that has not been fully accepted by WRD. To demonstrate the quality of surfacewater data collected with alternative equipment, thorough documentation of procedures and observations must be maintained. The responsibility for ensuring that alternative equipment is utilized correctly and for ensuring that documentation is comprehensive and is stored correctly is held by the Data Chief. At this time, the South Carolina District does not use any equipment that is not fully accepted by WRD.

\section{Indirect Measurements}

In many situations, especially during floods, it is impossible or impractical to measure peak discharges by means of a current meter or ADCP. There may not be sufficient warning for personnel to reach the site to make a direct measurement, or physical access to the site during the event may not be feasible.

A peak discharge determined by indirect methods is in many situations the best available means of defining the upper portions of the stage-discharge relation at a site. Because extrapolation of a stage-discharge relation, or rating, beyond twice the measured discharge at a gaging station is undesirable and may be unreliable, discharge measurements made by indirect methods during periods of high flows are important forms of data (Rantz and others, 1982, p. 334).

The District follows data-collection and computation procedures presented in Benson and Dalrymple (1967). That report includes policies and procedures related to site selection, field survey, identification of highwater marks, the selection of roughness coefficients, computations, and the written summary. The District also follows procedures for measurement of peak discharge by indirect methods presented in Rantz and others (1982, p. 273).

In addition to the general procedures presented in Benson and Dalrymple (1967), the District follows guidelines presented in other reports that describe specific types of indirect measurements suited to specific types of flow conditions. The slope-area method is described in Barnes (1967) and Dalrymple and Benson (1967). The USGS applies the Manning equation in application of the slope-area method. Procedures for selecting the roughness coefficient are described in Arcement and Schneider (1989). The computer-based tool, program C374, available to assist in computations of peak discharge with the slope-area method is discussed in Office of Surface Water Memorandum 83.07. Procedures for the determination of peak discharge through culverts, based on a classification system which delineates six types of flow, is described in Bodhaine (1982). The computer-based tool, program A526, available to assist in computations of peak discharge at culverts, is discussed in Office of Surface Water Memorandum 83.07. At sites where open-channel width contractions occur, such as flow through a bridge structure, peak discharge can be measured with methods described in Matthai (1967) and with the WaterSurface Profile Computation model (WSPRO) (Shearman, 1990). Debris-flow conditions, which are most common in small mountainous basins, are discussed in Office of Surface Water Memorandum 92.11.

Determinations of water-surface profiles along a stream channel in association with selected discharges are made when studies are performed that involve delineations of flood plains or when extensions are made to stagedischarge relations at streamflow sites. District personnel are required to follow the procedures associated with stepbackwater methods described in Davidian (1984). The computer-based tool used for assisting in the computations of water-surface profiles with step-backwater methods, WSPRO, is discussed in Office of Surface Water Memorandum 87.05. 
General guidelines that are followed by the District when making indirect measurements include those discussed in Office of Surface Water Memorandum 92.10 and Shearman (1990). Violation of any one of the general guidelines does not necessarily invalidate an indirect measurement (Office of Surface Water Memorandum 92.10). The decision to invalidate an indirect measurement is made by the Surface-Water Specialist.

The responsibility for ensuring that indirect measurements are performed correctly is held by the SurfaceWater Specialist. It is required that a review of procedures and documentation be performed annually for all peak discharge data published in the Annual Data Report. If deficiencies are found during the review, actions taken to remedy the situations include written notification of the deficiency to personnel making the original computation. After the corrective actions are taken, the computation is returned to the reviewer for approval. Measurements that are questionable and difficult to assess are reviewed by specialists outside the District, and the Surface-Water Specialist is responsible for ensuring that deficiencies identified by the outside party are corrected.

Determining when and where indirect measurements are made is the responsibility of the Data Chief for all stations maintained by the Hydrologic Data Surveillance and Analysis Section and the Project Section Chief for sites associated with specific projects. For this District, it is a general rule that indirect measurements are made at sites when peak flow at a site is estimated to be at least twice the discharge of the greatest measured flow.

It is the responsibility of field personnel to identify and flag high-water marks. Because the quality and clarity of high-water marks are best soon after a flood, personnel traveling in the field are required to have available in their field vehicles, at all times, nails, indelible markers, survey flagging, and copies of the District high-water mark documentation note sheet. A complete list of equipment to be maintained in each field vehicle is shown in Appendix 8. Each field vehicle is inspected on an annual basis as part of field-trip reviews. Because selection of a suitable reach of channel is an extremely important element in making an indirect measurement, at some streamflow gaging station sites the stream reach for indirect measurements at specified ranges of stage has been preselected, and that information has been included in the station description.

After each indirect measurement is computed, the graphs, field notes and data, plotted profiles, maps, calculations or computer output, and written analysis associated with the measurement are checked by Hydrologists assigned by the Section Chief. The information is organized in a labeled folder and is then filed in the general folder for the station. Indirect measurements made at sites not associated with a gaging station are filed by county in the Miscellaneous Indirect Measurement drawer in the backfile room.

The responsibility of maintaining the accuracy of the peak-flow data files, including computer data-base files, lies within the District (Office of Surface Water memorandum 92.10). It is the responsibility of the Data Chief to ensure that appropriate indirect-measurement results are entered into the peak-flow files. It is the responsibility of the Surface-Water Specialist to ensure that the peak-flow files are correct. For further discussion on the update and review of the peak-flow files, refer to the "Data-base Management" section in this QA Plan.

\section{Crest-Stage Gages}

Crest-stage gages are used as tools throughout the WRD for determining peak stages at otherwise ungaged sites, confirming peak stages at selected sites where recording gages are located, confirming peak stages where manometers or pressure transducers are used, and determining peak stages along selected stream reaches or other locations, such as upstream and downstream from bridges and culverts. The OSW requires quality-assurance procedures comparable to those used at continuous-record stations for the operation of crest-stage gages and for the computation of annual peaks at crest-stage gages (Office of Surface Water Memorandum 88.07). 
The operation of crest-stage gages is part of this District's surface-water program. Procedures followed by this District in the operation of crest-stage gages are presented in Rantz and others $(1982$, p. 9, 77, 78). One or more gages are maintained at each selected site where peak water-surface elevations are required on a stream. Upstream and downstream gages are maintained at culverts or other structures where water-surface elevations are required to compute flow through the structure and to establish the resulting type of flow.

Except at sites where crest-stage gages are used only to confirm or determine peak stages, stage-discharge relations are developed in association with the gage based on direct or indirect high-water measurements. Direct or indirect measurements are obtained at least every 5 years or as site conditions warrant to verify or adjust the rating. Streams gaged by crest-stage gages are usually small basins and peak discharges occur rapidly. Therefore, at least one team of hydrographers will be assigned to these gages in the District Flood Plan. Levels are run to the gage at least every 3 years or as soon as possible after significant changes in the gage because of damage to the gage, reconstruction, or other such situation. When extremely high peaks occur, an outside high-water mark to confirm the gage reading is found when possible, is described on the note sheet, and is flagged by a durable indicator so that the elevation of the high-water mark can be determined the next time levels are run.

Field observations are written on the standard form shown in Appendix 9. All field notes are required to include, at minimum, initials and last name of field personnel, date, time of observation, gage-height at time of inspection, and quality of mark (if corkline). In addition, the condition of the culvert, with respect to debris and sediment accumulation, must be documented. If upstream and downstream gages are maintained, the peak stage at each gage is plotted on the graph of upstream stage versus downstream stage in the field folder to ensure the marks agree with the existing relation. If the marks do not agree with the existing relation, marks are rechecked before departure, and high-water marks are documented.

The responsibility for ensuring that correct data-collection procedures are used by personnel is held by each Field Office Chief. This responsibility is carried out by reviewing all field notes by personnel with less than 1 year experience and annually as part of field trip reviews for all other personnel. When a deficiency in data-collection activities is identified, the problem is remedied by additional training provided by the Field Office Chief.

Policies and procedures for computation of peak discharges at crest-stage gages and associated documentation are presented in this report in the section entitled "Processing and Analysis of Stage and Streamflow Data."

\section{Artificial Controls}

Artificial controls, including broad-crested weirs, thin-plate weirs, and flumes, are built in stream channels for the purpose of simplifying the procedure of obtaining accurate records of discharge (Rantz and others, 1982, p. 12). Such structures serve to stabilize and constrict the channel at a section, reducing the variability of the stage- discharge relation.

Artificial controls are used at some gaging stations maintained by this District. In situations where artificial controls are installed as permanent structures, it is District policy that stage-discharge relations are determined by making current-meter measurements throughout the range of stage. Portable flumes are used by District personnel in situations that include very small streams that can not be measured using current meter or volumetric methods. These portable devices are applied according to methods described in Buchanan and Somers (1969, p. 57) and Rantz and others (1982, p. 263). 
Ensuring the correct design and installation of artificial controls for this District is the responsibility of the Surface-Water Specialist. When installing an artificial control, the District personnel take into account the criteria for selecting the various types of controls, principles governing their design, and the attributes considered to be desirable in such structures (Carter and Davidian, 1968, p. 3; Rantz and others, 1982, p. 15 and 348; and Kilpatrick and Schneider, 1983, p. 2 and 44).

When field inspections of artificial controls are performed, specific information pertaining to control conditions are written on the field note sheets for the purpose of assisting in analysis of the surface-water data. These notes include debris accumulation on the control or fill upstream of the control. Regular maintenance at artificial controls include clearing the control and inspecting for leaks. Discharge measurements are obtained before and after the control is cleared. When problems pertaining to artificial controls are encountered by field personnel, the Field Office Chief is informed and remedial action taken as soon as possible.

\section{Flood Conditions}

Flood conditions present problems that otherwise do not occur on a regular basis. These problems can include difficulties in gaining access to a streamflow gage or measuring site because roads and bridges are flooded, closed, or destroyed. Debris in the streamflow can damage equipment and present dangers to personnel collecting the data. Rapidly changing stage or conditions requiring measurements to be made at locations some distance away from the gage can create problems in associating a gage height to a measured discharge.

The District maintains a flood plan so that high-priority surface-water data associated with flood conditions are collected correctly and in a timely manner. The flood plan describes responsibilities before, during, and after a flood, informational-reporting procedures, and field-activity priorities. The flood plan serves as a central reference for emergency communications, telephone numbers for key District personnel, and codes for accessing streamflow gages equipped with telemetry.

It is the responsibility of the Data Chief for ensuring that the flood plan includes all appropriate information, including updated information. The flood plan is reviewed annually by the Data Chief. A copy of the flood plan is provided to all personnel in the Hydrologic Data Surveillance and Analysis Section, the Surface-Water Specialist, and other District personnel on request. Each individual that receives a copy of the plan keeps it in their field vehicle if one is assigned to them. Otherwise, it is kept in their office. It is the responsibility of the Field Office Chiefs to ensure that individuals that receive a copy of the plan are fully versed on the content of the flood plan.

During a flood, coordination of flood activities is performed by the Data Chief with assistance from the Field Office Chiefs. For personnel that are not already in the field, their first responsibility during flood conditions is to report to their office prepared for overnight travel. For personnel that are already in the field, their first responsibility during flood conditions is to make measurements at high priority stations and call their Field Office Chief. Personnel who arrive at a gaging station to find that a flood has occurred are responsible for calling their Field Office Chief if the flood water has receded or immediately making a discharge measurement if the stage is still above flood stage. South Carolina District personnel apply methods discussed in Rantz and others (1982, p. 60) for determining peak stage at gaging stations.

District personnel follow policies and procedures stated in a number of publications and memorandums when collecting surface-water data during floods. Techniques for current-meter measurements of flood flows are presented in Rantz and others (1982, p. 159-170). Procedures for identifying high-water marks for indirect discharge measurements are presented in Benson and Dalrymple (1967, p. 11). Adjustments applied to make measured flow hydraulically comparable with recorded gage height when discharge measurements are made a 
distance from the gaging station are presented in Office of Surface Water Memorandum 92.09 and in Buchanan and Somers $(1969$, p. 54). It is the responsibility of all personnel with questions about particular policies or procedures related to flood activities, or who recognize their need for further training in any aspect of flood-data collection, to address their questions to their Field Office Chief.

Review of District activities related to floods is the responsibility of the Surface-Water Specialist. This review includes seeing that guidelines and priorities spelled out in the flood plan are followed and that the guidelines appropriately address District requirements for obtaining flood data in a safe and thorough manner. When deficiencies are identified by the reviewer, deficiencies are remedied by written communication to the Data Section Chief, the Project Section Chief, and the District Chief.

\section{Low-Flow Conditions}

Streamflow conditions encountered by District personnel during periods of low flow are typically quite different from those encountered during periods of medium and high flow. Low-flow discharge measurements are made to define or confirm the lower portions of stage-discharge relations for gaging stations, as part of seepage runs to identify channel gains or losses, and to help in the interpretation of other associated data. Additionally, low-flow measurements are made to define the relation between low-flow characteristics in one basin and those of a nearby basin for which more data are available (Office of Surface Water memorandum 85.17).

In many situations, low flows are associated with factors that reduce the accuracy of discharge measurements. These factors include algae growth that impedes the free movement of current-meter buckets and larger percentages of the flow moving in the narrow spaces between cobbles. When natural conditions are in the range considered by the field personnel to be undependable, the cross section is physically improved for measurement by removal of debris or large cobbles, construction of dikes to reduce the amount of non-flowing water, or other such efforts (Buchanan and Somers, 1969, p. 39). After modification of the cross section, the flow is allowed to stabilize before the discharge measurement is initiated.

District policy requires that point-of-zero-flow measurements be made by field personnel for all wading measurements at stations with an obvious control section.

The individual responsible for ensuring that District personnel use appropriate equipment and procedures during periods of low flow is the Data Chief. Determination that appropriate procedures are used for datacollection activities during low-flow conditions is accomplished by reviewing notes during the records computation process. The Surface-Water Specialist is responsible for providing answers to questions from District personnel pertaining to data collection during periods of low flow.

\section{Cold-Weather Conditions}

Surface-water activities in this District includes making streamflow-discharge measurements during cold weather conditions. Cold temperatures, wind, snow, and ice can create difficulties in collecting data. These factors also can create dangers to field personnel. The highest priority in collecting streamflow data during winter periods is employee safety.

For gaging stations where the stream is subject to freezing during the winter, discharge measurements under ice cover and during periods of partial ice cover are useful for analysis and determination of flow throughout winter periods. District personnel are required to follow procedures for discharge measurements under ice cover presented in Buchanan and Somers (1969, p. 42). This same publication includes procedures for discharge measurements made by wading or discharge measurements from cableways and bridges when debris and ice are 
in the streamflow. District personnel also follow procedures to collect winter streamflow data as presented in Rantz and others (1982, p. 124). Additionally, guidelines on equipment for measurement of flow under ice is provided in Office of Surface Water Memorandum 84.05.

Presently, OSW views the preferred metering equipment for discharge measurements for slush-free conditions under ice cover to be a type AA current meter built with a Water Survey of Canada (WSC) winter-style yoke with a conventional metal-cup rotor. For conditions where slush ice is present, the Office of Surface Water views the preferred metering equipment to be the WSC winter-style yoke with a polymer rotor (Office of Surface Water Memorandum 88.18). Although polymer rotors are not allowed (Office of Surface Water Memorandum 90.01) during all other conditions, the superior ability of the polymer rotor to shed slush ice and retard freezing in ice-covered streams is considered to be more important than the turbulent-flow-related inaccuracies associated with the rotor (Office of Surface Water Memorandum 92.04). The OSW also views the regular AA meters with conventional metal-bucket rotors to be acceptable for use in slush-free conditions if cutting the required larger holes through the ice is feasible (Office of Surface Water Memorandum 92.04).

\section{PROCESSING AND ANALYSIS OF STAGE AND STREAMFLOW DATA}

The computation of streamflow records involves the analysis of field observations and field measurements, the determination of stage-discharge relations, adjustment and application of those relations, and systematic documentation of the methods and decisions that were applied. Streamflow records are computed and published for each gaging station annually (Rantz and others, 1982, p. 544)

This section of the QA Plan includes descriptions of procedures and policies pertaining to the processing and analysis of data associated with the computation of streamflow records. The procedures followed by the South Carolina District coincide with those described in Rantz and others (1982) and in Kennedy (1983).

\section{Measurements and Field Notes}

The gage-height information, discharge information, control conditions, and other field observations written by personnel onto the measurement note sheets and other field note sheets form the basis for records computation for each gaging station. Measurements and field notes that contain original data are required to be stored indefinitely (Hubbard, 1992).

Measurements and other field notes for the water year that is currently being computed are filed in the current folder using field-trip data processing procedures shown in Appendix 10. District policy requires that discharge measurements and inspection information will be entered in the NWIS data base within 5 days of the completion of the field trip. Measurements and notes for previous water years are filed in the backfile room.

It is District policy that all discharge measurements are checked. The measurements are checked by reviewing the mathematics and other items listed in Kennedy (1983, p. 7).

\section{Continuous Record}

Surface-water gage-height data are collected as continuous record (hourly, 15-minute, or 5-minute values, for example) in the form of electronic data files. Streamflow records are computed by converting gage-height record to discharge record through application of stage-discharge relations. Ensuring the accuracy of gage-height record is, therefore, a necessary component of ensuring the accuracy of computed discharges. 
Gage-height record is assembled for the period of analysis in as complete a manner as possible. Periods of inaccurate gage-height data are identified then corrected (see the section "Datum corrections, gage-height corrections, and shifts") or deleted as appropriate. In general, erroneous unit values are corrected by interpolation. Items included in the assembly of gage-height record and procedures for processing the data are discussed in Kennedy (1983, p. 6) and Rantz and others (1982, p. 560 and 587).

Most continuous record stations in the South Carolina District are equipped with satellite telemetry equipment with data-logger back-up. Field personnel are responsible for reviewing DCP data from their stations on a routine basis. In addition, all DCP data are plotted and reviewed on a daily basis by the Columbia Field Office Chief or designee and erroneous unit data are corrected. The DCP data are used as the primary record and missing unit values are replaced with BDR data, if available. Monthly plots of unit gage-height are generated during field-trip data processing and maintained in the current folder.

\section{PROCESSING OF REAL-TIME STREAMFLOW DATA}

A necessary and critical element in maintaining accurate streamflow records on a real-time basis is the need for rating analysis and shift application as soon as practicable after a discharge measurement has been made. The South Carolina District's policy is that rating analyses and shift applications will be performed using the following procedures for data disseminated on the District's public web page: http://sc.water.usgs.gov.

Shift adjustments are applied for measurements that do not verify the rating curve in use within the measurements rated accuracy. These adjustments will be applied during the 5-day processing period following each field trip by each field technician. The appropriate Field Office Chief should be consulted for shift adjustments that modify the computed discharge by more than 20 percent. During extreme events, such as floods and droughts, discharge measurement information will be called in immediately to the appropriate Field Office Chief or Data Section Chief for immediate application.

\section{Web Page Presentation Format}

South Carolina District real-time data are served from computers located in Columbia maintained by the District. The National Water Information System-Web (NWIS-W) software is used to conform to national USGS standards. The webmaster is responsible for adding and deleting real-time data to the web page at the instruction of the Data Section Chief.

\section{Review of Real-Time Streamflow Data}

Real-time streamflow data that are disseminated on the public web page must be reviewed frequently to ensure their quality and to prevent the distribution of erroneous information. The South Carolina District utilizes both automated and manual review procedures to meet this objective.

Automated procedures that have been implemented by the South Carolina District include the setting of minimum and maximum threshold values for stage and discharge and their rates of change. If exceeded, these

settings will initiate warnings of potential errors that will be delivered by the webmaster to the appropriate district personnel. The Data Section Chief is the South Carolina District person designated to receive and act upon these messages. The Columbia Field Office Chief is the primary backup for this procedure. 


\section{Error Handling}

There are two general types of errors associated with streamflow data that are delivered by the real-time system and disseminated on the Internet. The first are persistent-type problems usually associated with some type of equipment failure whether in data collection or transmission, but could also be related to ice effects. Because of the nature of the problem, they generally occur on a continuing basis for more than a single recording interval. The second are the intermittent-type problems, which are often the result of a data transmission error. These often show up as either a zero or an unreasonably large value. These extreme values will be filtered from the web page by populating the "very high" threshold in ADAPS with the gage height of the instrument shelf and the "very low" threshold in ADAPS with the value of 0.01 feet. Erroneous values are detected and corrected during routine review by the field technician or by review of the daily plots by the Field Office Chief. The decision to remove a station from the web page rests with the Data Section Chief.

\section{Data Qualification Statements}

WRD Technical Memorandum 95.19 requires that streamflow data made available on the web should be considered provisional until the formal review process has been completed. To ensure that everyone who accesses data from the web are aware of this, data qualification statements must be included at key locations with a clickable heading "Provisional Data Subject to Revision" on all real-time data pages.

\section{Records and Computation}

In general, records are computed by field personnel and checked and reviewed by personnel assigned by the Field Office Chiefs. Records are returned to the individual that worked the record if computational errors are found by the checker. The individual checking the record is responsible for verifying all math computations, datum and shift corrections, rating analysis, and analysis documentation. The individual reviewing the record is responsible for ensuring all backfile documentation is in order and that manuscripts and data tables meet publication standards. Most records are assigned to individuals for working and checking at the beginning of the computational period. Assignments are made by the Data Section Chief and Field Office Chiefs and are based on experience and workload.

\section{Procedures for Working and Checking Records}

Procedures for ensuring the thoroughness, consistency, and accuracy of streamflow records are described in this section of the QA Plan. The goals, procedures, and policies presented in this section are grouped in association with the separate components that are included in the records-computation process.

\section{Gage Height}

The accuracy of surface-water discharge records depends on the accuracy of discharge measurement, the accuracy of rating definition, and the completeness and accuracy of the gage-height record (Office of Surface Water Memorandum 93.07). Computation of streamflow records includes ensuring the accuracy of gage-height record by comparisons of gage-height readings made by use of independent reference gages, comparison of inside and outside gages, examination of high-water marks, comparisons of the redundant recordings of peaks and troughs by use of maximum and minimum indicators, examination of data obtained at crest-stage gages, and confirmation or updating of gage datums by levels. 
Records computation includes examination of gage-height record to determine if the record accurately represents the water level of the body of water being monitored. Additionally, it includes identifying periods of time during which inaccuracies have occurred and determining the cause for those inaccuracies. When possible and appropriate, inaccurate gage-height record is corrected. When corrections are not possible, the erroneous gage- height data are removed from the set of data used for streamflow records computation.

All inspections are annotated on the final primary sheets. Periods of record obtained by back-up recorder are clearly identified on the primary and station analysis.

\section{Levels}

Errors in gage-height data caused by vertical changes in the gage or gage-supporting structure can be measured by running levels. Gages can be reset or gage readings can be adjusted by applying corrections based on levels (Kennedy, 1983, p. 6).

Procedures for computing records for each station include the thorough evaluation of level notes completed during the year and any associated datum corrections. Information from the front sheet is transferred to the historical level summary. The individual computing the record is required to check field notes for indications that the gages were reset correctly by field personnel. If gages were not reset to agree with levels, remedial action is coordinated with the appropriate Field Office Chief. The individual computing the records makes appropriate adjustments to the gage-height record by applying datum corrections.

\section{Rating}

The development of the stage-discharge relation, also called the rating, is one of the principal tasks in computing discharge record. The rating is usually the relation between gage height and discharge (simple rating). Ratings for some special sites involve additional factors such as rate of change in stage or fall in slope reach (complex ratings) (Kennedy, 1983, p. 14).

District personnel follow procedures for the development, modification, and application of ratings that are described in Kennedy (1984). District personnel also follow guidelines pertaining to rating and records computation that are presented in Kennedy (1983, p. 14) and in Rantz and others (1982, chap. 10-14 and p. 549).

For each gaging station, the most recent digital rating table can be obtained by generating an electronic file or hard copy from the ADAPS data base (a hard copy also is maintained in the current folder). A graphical plot of the most recent rating can be obtained by generating a plot file to send to the HP-650C Color Plotter (the original is maintained in the District rating curve drawer).

A copy of the current rating curve is maintained in the current folder. This copy is updated after each field trip and is used as a work copy for determining shift adjustments. In general, new ratings are not drawn unless a permanent change in the control is documented or a long-term trend develops. Original rating curves are updated after records complete the review process for publication in the Annual Data Report. New ratings are considered provisional until the records review process is completed. Questions concerning rating development are directed to Field Office Chiefs, the Data Section Chief, or the Surface-Water Specialist. 


\section{Datum corrections, gage-height corrections, and shifts}

A correction applied to gage-height readings to compensate for the effect of settlement or uplift of the gage is usually measured by levels and is called a "datum correction" (Kennedy, 1983, p. 9). Datum corrections are applied to gage-height record in terms of magnitude (in feet) and in terms of when the datum change occurred. In the absence of any evidence indicating exactly when the change occurred, the change is assumed to have occurred gradually from the time the previous levels were run, and the correction is prorated with time (Rantz and others, 1982, p. 545) Datum corrections are applied when the magnitude of the vertical change is greater than 0.02 foot.

A correction applied to gage-height readings to compensate for differences between the recording gage and the base gage is called a "gage-height correction" (Rantz and others, 1982, p. 563). These corrections are applied in the same manner as datum corrections by use of the same computer software. Gage-height corrections are applied so the recorded data are made to agree with base-gage data. These corrections are applied when the difference between the recording gage and the base gage is greater than 0.02 foot or if failure to apply the correction results in discharge computations greater than 3 percent in error.

A correction applied to the stage-discharge relation, or rating, to compensate for variations in the rating is called a shift. Shifts reflect the fact that stage-discharge relations are not permanent but vary from time to time, either gradually or abruptly, because of changes in the physical features that form the control at the gaging station (Rantz and others, 1982, p. 344). Shifts can be applied to vary in magnitude with time and with stage (Kennedy, 1983, p. 35). In general, shifts are applied by proration with time and stage between hydrologic events. Shifts are computed based on the quality (accuracy) of the discharge measurement and by using variable shift diagrams. Hard copies of the datum-corrections file and shift file are backfiled with the annual record.

\section{Hydrographs}

A discharge hydrograph is a plot of daily mean discharges versus time. The date is aligned with the horizontal axis and the discharge is aligned with the logarithmic vertical axis. In the process of computing station records, this hydrograph is a useful tool in identifying periods of erroneous information, such as incorrect shifts or datum corrections. Additionally, hydrographs are helpful when estimating discharges for periods of undefined stage-discharge relation, such as during backwater or ice conditions, and in estimating discharges for periods of missing record.

Information placed on the hydrograph for each station includes station name, station number, water year, plot of daily mean discharge data, and plots of measurements. Final hydrographs show estimated daily discharges in red and are backfiled with the annual record. A District program called "HYDCOMP" can be used to determine suitable comparison stations and estimate daily mean discharge valves by regression analysis for periods of missing data. The District Surface-Water Specialist will provide training for personnel that choose this method for estimating missing record.

\section{Station Analysis}

A complete analysis of data collected, procedures used in processing the data, and the logic upon which the computations were based is documented for each year of record for each station to provide a basis for review and to serve as a reference in case questions arise about the records at some future date (Rantz and others, 1982, p. 580). Topics discussed in detail in the station analysis include evaluation of the gage-height record, datum corrections, rating analysis, techniques for estimating missing record, and general remarks. The station analysis is 
written by the individual responsible for working the annual record for publication. An electronic file containing the most recent station analysis is maintained on the SUN system in the directory "annualreport/sta.analyses.xx", where " $\mathrm{xx}$ " is the last two digits of the water year for which the analysis was prepared.

\section{Winter records}

Computing records that represent winter periods for gaging stations involves procedures that are not applicable to records that represent other times of the year. The formation of ice in stream channels or on section controls affects the stage-discharge relation by causing backwater; the effect varies with the quantity and nature of the ice, as well as with the discharge (Rantz and others, 1982, p. 360). During some conditions the recorded gageheight data may be accurate, although the actual stage-discharge relation may be undeterminable and unstable. An example of this condition would be when surface ice forms on the stream, but the stilling well remains unfrozen and the water level in the stilling well represents the backpressure caused by the ice in the channel. During other conditions the recorded gage-height data are inaccurate, resulting in periods of missing gage-height record. An example of the latter would be when a stilling well or the intakes to the stilling well are frozen. Gaging stations maintained by the South Carolina District are rarely, if ever, affected by frozen conditions and further discussion is unnecessary.

\section{Furnished records}

Surface-water data collected under the supervision of other agencies, organizations, or institutions are received by this office. These data are used to document diversions by a municipality and to provide month-end reservoir elevation data at partial-record stations for publication in the Annual Data Report.

\section{Daily values table}

With few exceptions, for each gaging station operated by the WRD a discharge value is determined and stored for each day. The daily values table generated by use of the records-computation software represents what discharge values are stored for each day of the water year. The final daily values table is flagged by the individual checking the discharge record. Instructions for finalizing the unit and daily values, as well as generating the final table with statistics, are given in Appendix 11.

\section{Manuscript and annual report}

When records computation for the water year has been completed and the data collected and analyzed by District personnel have been determined to be correct and finalized, the surface-water data for that water year are published along with other data in the District's annual data report. The annual data report is part of the series titled "U.S. Geological Survey Water-Data Reports." Information presented in the annual data report includes daily discharge values during the year, extremes for the year and period of record, and various statistics. Additionally, manuscript station descriptions are presented in the annual data report. Information contained in the manuscript includes physical descriptions of the gage and basin, history of the station and data, and statements of cooperation.

In preparing the annual data report for publication, the District follows the guidelines presented in the report, "WRD Data Reports Preparation Guide," by Charles E. Novak, 1985 edition. 


\section{District Checkoff List}

A checklist of the basic computational procedures for individuals working and checking daily discharge records is shown in Appendix 12. This checklist is discarded by the individual reviewing the record as the backfile package is prepared. In addition, a checklist indicating the individual assignments for working and checking records is posted in each Field Office at the beginning of each computational period.

\section{Review of Records}

After streamflow records for each station have been computed and checked, records for each of the District's gaging stations are reviewed by the Data Section Chief or his designee. District policy requires that at least 10 percent of the records are reviewed by the Surface-Water Specialist. The goal of the review is to ensure that proper methods were applied throughout the process of obtaining the surface-water data and computing the record. In addition, the original data is distributed to the appropriate archive files and the final camera-ready page is reviewed. In the event that computational errors are discovered by the reviewer, the record is returned to the checker to be corrected. This will require that the final flag be reset to provisional to allow recomputations. Therefore, the checker must be extremely thorough.

\section{Crest-Stage Gages}

Records for crest-stage gages are computed with goals and procedures similar to those for other gaging stations. The field notes are examined for correctness and accuracy. Peak stages recorded by crest-stage gages are cross referenced with other available information; the dates of the peaks are determined by analyzing available precipitation data and peak data from recording gages within the same basin or from nearby basins.

A discussion on the policies and procedures used for field aspects of collecting data at crest-stage gages is included in this report in the section "Collection of Stage and Streamflow Data." The discussion in this section describes the analysis and office documentation of crest-stage data. This section does not pertain to data collected at crest-stage gages installed solely for the purpose of confirming peak stages at sites where manometer or pressure-transducer gages are used.

At sites where crest-stage gages are used to compute peak discharges, an initial stage-discharge relation, or rating, is developed for the site by direct or indirect high-water measurements. The rating is verified or adjusted on the basis of subsequent direct or indirect high-water measurements.

For each station, a list of all measurements is maintained and each measurement is assigned a chronological number. For each station, a graphical plot of the current rating along with each recent and each notably high stagedischarge measurement is made readily available to those who check and review the station record by updating the work copy of the rating curve in the current folder. Current station descriptions and a summary of levels are maintained in the current folder. A brief station analysis is written each year describing computation of the annual peak, identifying which rating was used and the type of flow condition, describing how the dates of the peaks were determined, and comparison of the annual peak to the peak for the period of record.

Responsibility for assigning the personnel for each crest-stage-gage station is held by the Data Section Chief. Computations are checked by examination of all aspects of the computation, including field notes. Stations with computational errors are returned to the individual that computed the record for corrective action. The corrected record is returned to the individual checking the record to complete the process. 
Responsibility for ensuring the correct computation of annual peaks at crest-stage gages is held by the Data Section Chief. Review of the crest-stage gage computations is performed by the Surface-Water Specialist by selecting three stations to review each year. When incorrect actions or procedures are identified during the review, the problems are remedied by summarizing the deficiencies in writing with copies to the worker, checker, and Data Section Chief.

Responsibility for updating the Peak-Flow File promptly after peak data have been finalized is held by the Data Section Chief. A current listing of annual peaks is maintained in the station folder for review purposes (Office of Surface Water Memorandum 88.07).

\section{OFFICE SETTING}

Maintaining surface-water data and related information in a systematic and organized manner increases the efficiency and effectiveness of data-analysis and data-dissemination efforts. Good organization of files reduces the likelihood of misplaced information; misplaced data and field notes can lead to analyses based on inadequate information, with a possible decrease in the quality of analytical results.

This section of the QA Plan includes descriptions of how station folders, reference maps, levels documentation, and other information related to surface-water data are organized and maintained. Additionally, this section provides an overview of how work activities are designed to be carried out within the office setting.

All level, inspection, and discharge measurement notes for the current year are maintained in the current folder for each station in the appropriate Field Office. All field notes are forwarded to the District Office during the records computation process. Data are archived in the District Office after the review process has been completed.

\section{Work Plan}

Each year field trips are subject to change to accommodate changes in the data collection network or to rotate field trips for quality control purposes. Field trip and records assignments are determined at the beginning of each water year by the Data Section Chief and Field Office Chiefs. Hard copies of updated field trips are distributed to all field personnel and records assignments are annotated on the station checklist posted in each Field Office.

\section{File Folders for Surface-Water Stations}

This section of the QA Plan describes the location and makeup of hard-copy files associated with surfacewater data. Information pertaining to files maintained in computer storage can be found in the "Data-base Management" section of this report.

For each gaging station, a separate set of file folders is maintained by station number in downstream order. The "current" folder contains data collected during the current water year and documentation necessary for records computation, including the level summary, a work-copy of the rating curve, rating table, and station description. Current folder files are maintained by each Field Office. The "backfile" folders contain historical information and are maintained by the District Office. Extraneous items are removed from the current files and distributed to the appropriate backfile after the records are reviewed and finalized for publication. The set of backfiles is grouped for each station as follows: 
- Annual Summary (No. 1) Folder--contains backfile package for each water year, in chronological order.

- Measurement Summary (No. 2) Folder--contains discharge measurement information for each water year using standard 9-207 format, in chronological order.

- Rating Table (No. 3) Folder--contains a copy of each rating in tabular format, in numerical order.

- Rating Curve (No. 4) Folder--contains the original rating curves that have been superseded, in numerical order.

- Statistical (No. 5) Folder--contains any statistical information, including flood frequency analysis.

- General (No. 6) Folder--contains station descriptions that have been superseded, indirect measurement documentation, photographs, and any other information that should be archived.

\section{Field-Trip Folders}

Field-trip folders contain the current station description, location maps, copies of discharge measurements at various stages, copy of level summary, copy of current rating curve and table, and DCP and/or BDR program. Field personnel are responsible for maintaining and updating field folders. Field folders are reviewed for content by Field Office Chiefs on an annual basis during field-trip reviews.

\section{Levels}

Level notes are backfiled by station number, in downstream order, in the backfile room in the District Office. Level notes are filed in chronological order behind measurement and inspection notes.

\section{Discontinued Stations}

Files for discontinued surface-water stations are maintained in the backfile room in the District Office in the same files as the active stations. This minimizes file movement as stations are discontinued or reactivated and ensures that all historical data are centrally located.

\section{Map Files}

The South Carolina District maintains three map files, all of which use USGS 7.5-minute topographic maps. The drainage area and river mile maps are kept locked to limit access (contact the Data Section Chief or Project Section Chief for access). Several copies of each map are filed (unlocked) for general use, including field work. All map files use a numbering scheme that are located using an index posted at the map cabinet.

\section{Archiving}

All WRD personnel are directed to safeguard all original field records containing geologic and hydrogeologic measurements and observations. Selected material not maintained in field offices are placed in archival storage. Detailed information on what records have been removed to archival centers should be retained in the District or project office (Water Resources Division Memorandum 77.83). The types of original data that should be archived include, but are not limited to, recorder charts and tapes, original data and edited data, observer's notes and readings, station descriptions, analyses, and other supporting information (Water Resources Division memorandum 92.59 and Hubbard, 1992, p. 12). At this time there is an agreement between WRD and the Federal Records Centers (FRC) of the National Archives and Records Administration to archive original-data records (memorandum from the Chief, Branch of Operational Support, May 7, 1993). 
Surface-water information is sent to the FRC from the South Carolina District every 3 years. The Data Section Chief is responsible for deciding what information is sent to the FRC, for ensuring that the information is properly packed and logged, and for ascertaining that the information is received by the FRC. In general, all routine inspections and discharge measurements more than 3 years old will be sent to the FRC. All levels and measurements that define the extreme upper and lower ranges of the rating curve will be maintained in the District. Records of exactly what has been archived are maintained in a notebook by a Data Section Chief designee. Personnel who have questions concerning archiving procedures should address their questions to the Data Section Chief. Personnel who receive requests for information that require accessing archived records should contact the Data Section Chief.

Surface-water data collected for special studies or projects must be archived. Data can be archived in the District backfiles or the FRC. Each project chief is responsible for packing appropriate data in archive boxes and providing a written summary of the contents to the Project Section Chief. The Project Section Chief determines which archive method is most suitable and coordinates the archiving with the Data Section Chief.

\section{Communication of New Methods and Current Procedures}

Updated or clarified policies are communicated to field personnel by written summary, usually by e-mail. Personnel in the Hydrologic Data Surveillance and Analysis Section meet at least semiannually to discuss, in detail, new policies and procedures.

\section{COLLECTION OF SEDIMENT DATA}

Surface-water activities in the District include the collection, analysis, and publication of sediment data. The District operates in adherence to policies related to sediment set forth by the OSW.

Responsibility for the sediment discipline was transferred from the Office of Water Quality (OWQ) to the OSW in 1985 (Office of Surface Water Memorandum 92.08). The policies and procedures related to sediment followed by the District are described in selected WRD publications and in memorandums issued by OSW, the Office of Water Quality, and WRD. Techniques adopted by the USGS and followed by this District are presented in Knott and others (1992). The District also follows procedures presented in three publications for the TWRI series:

Book 3, Chapter C1 ..... "Fluvial Sediment Concepts" by Guy (1970),

Book 3, Chapter C2 ..... "Field Methods for Measurement of Fluvial Sediment" by Guy and Norman (1970),

Book 3, Chapter C3 ..... "Computation of Fluvial-Sediment Discharge" by Porterfield (1972).

Although no additional TWRI chapters have been written to supersede the above-mentioned reports, OpenFile Report 86-531 "Field Methods for Measurement of Fluvial Sediment" by Edwards and Glysson (1988) essentially replaces Book 3, Chapter C2 (Water Resources Division Memorandum 71.73, Office of Surface Water Memorandum 88.17, and Office of Surface Water Memorandum 93.01).

A summary of memorandums issued since 1971 related to sediment and sediment transport is provided in Office of Surface Water Memorandum 92.08. A summary of documentation that describes instrumentation and field methods for collecting sediment data is provided in Office of Surface Water Memorandum 93.01. 


\section{Sampling Procedures}

District personnel collect suspended-sediment data by using sampling methods that include the Equal Width Increment (EWI) method and the point-sample method. Automatic pumping-type samplers are not currently used by the South Carolina District for sediment sampling.

Field methods for sediment sampling are documented in Office of Surface Water Memorandum 93.01. Water samples obtained for the analysis of sediment concentration and particle size are not composited (Office of Surface Water Memorandum 93.01 and Office of Water Quality Memorandum 76.17). For samples that are split, the cone splitter is used (Office of Water Quality Memorandum 80.17).

Policy for the collection and publication of bedload data is provided in Office of Surface Water Memorandum 90.08. This memorandum supersedes policy and guidelines provided in previous Office of Water Quality Memorandums 76.04, 77.07, 79.17, and 80.07, as well as Water Resources Division Memorandum 77.60. Among the policies stated in Office of Surface Water Memorandum 90.08, which are followed by the District, is one stating that three cross-sectional procedures are used for bedload sampling: the Single Equal Width Increment (SEWI) method, the Multiple Equal Width Increment (MEWI) method, and the Unequal Width Increment (UWI) method. Additionally, it is stated in Office of Surface Water memorandum 90.08 that it is the responsibility of the field personnel to select the procedure that is optimal for the local condition. Bedload samples in some situations are analyzed individually and in other situations are analyzed as a composite. Until sampling variability for a particular site is understood by those analyzing the data, all samples are required to be analyzed individually.

The individual in the District responsible for scheduling sediment-collection activities at gaging stations is the Data Section Chief. The individual responsible for ensuring that District personnel use correct procedures to collect sediment data is the Data Section Chief. This individual establishes whether or not correct procedures are being used by completing sample collection trips with field personnel at least once every 2 years. Answers to questions from District personnel concerning sediment-sampling techniques are provided by the Data Section Chief.

\section{Field Notes}

District personnel are required to fill out note sheets each time a site is visited for the purpose of sediment sampling. The employee completes the note sheet in its entirety before leaving the site. Original observations written on the note sheets are not to be erased; data are corrected by crossing out the original observations and writing the correct information near the original value. The goal of placing information on the field note sheet is to describe the equipment and methods used during the site visit as well as to describe relevant conditions or changes (Office of Surface Water Memorandum 91.15). For each site visit, information included on the note sheet includes, at minimum, site identification, field personnel name (initials and last name), date, time, sampling equipment, and method.

Upon completion of each field trip, field notes are placed in the current folder. Field notes are checked during the records review process.

\section{Equipment}

Care and maintenance of the sediment-data-collection equipment is the responsibility of the field personnel that use the specific equipment. Parts replacement and repair of damaged equipment is accomplished by communication with the Field Office Chief. It is the responsibility of the Data Chief to ensure that appropriate equipment is used at all sampling sites. Sampling equipment is selected based on the constituents that are being 
investigated, the type of analyses that are to be performed, and site conditions, including velocity and maximum depth of water. The District follows equipment-design criteria and guidelines referenced in Office of Surface Water Memorandum 93.01.

\section{Sample Handling and Storage}

The quality of sediment data provided by a sediment laboratory is affected by the quality of the samples received from the field (Knott and others, 1992, p. 2). District personnel are required to prepare sample labels, analysis instructions, and sample documentation according to guidelines presented in Knott and others (1992).

Prior to when sample containers are obtained for use on field trips, they are stored in the Field Office. Once the containers have been filled with sediment samples, the samples are stored for the remainder of the field trip in their protective shipping crates. After the field trip, samples are shipped to the Kentucky District Sediment Lab for analysis.

\section{High-Flow Conditions}

High-flow conditions at most streams, unless the streams are subject to the effects of backwater, are associated with high-energy conditions. The sediment load and particle sizes associated with high flows are significant factors in sediment studies performed by the District. To ensure that field personnel are aware of their responsibilities in obtaining sediment samples at appropriate sites during high-flow conditions, priority sampling sites are listed in the District Flood Plan. The individual responsible for ensuring that sediment samples are obtained during opportunities provided by high-flow conditions is the Data Chief. The individual responsible for ensuring that the proper sampling equipment and methods are used during high-flow conditions is the Data Chief. The Data Chief is responsible for providing answers to District personnel who have questions concerning high-flow sampling equipment or sampling procedures.

\section{Cold-Weather Conditions}

Sediment-sampling activities in this District do not include obtaining samples during periods of subfreezing temperatures.

\section{Site Documentation}

A station description is prepared for each new sediment-sampling site. At sampling sites where streamflowgaging activities occur, the description of sediment activities is included in the streamflow-gaging-station description. A list of elements included in each station description, along with an explanation of what items are included with each element, is presented in the attachment to Office of Surface Water memorandum 91.15. At sites where sediment samples are collected but other streamflow data are not collected, the station descriptions are structured similarly to those for streamflow-gaging stations, and contain similar informational items (Kennedy, 1983, p. 2). At sampling sites where gage houses have been installed, station descriptions are kept in the gage house for the purpose of providing field personnel with information pertinent to sediment-sampling procedures for that particular site. Station descriptions are included in the field folder and are maintained in the office files. Each description includes specific information explaining where the site samples are to be taken and what method is to be used.

The responsibility of ensuring that field copies of station descriptions located at gage houses are kept current is held by field personnel. Station descriptions are kept current by annual review and updating by the individual that processes the sediment-station data. Station descriptions are reviewed to ensure that they are current by the Data Chief. These reviews are made at least every 3 years. 


\section{PROCESSING AND ANALYSIS OF SEDIMENT DATA}

Sediment and associated streamflow data are compiled to produce sediment records for specific sites. Data processing of periodic measurements consists of four steps: tabulation, evaluation, editing, and verification (Office of Surface Water Memorandum 91.15). The District follows the considerations and guidelines presented in Porterfield (1972), Guy (1969), and Office of Surface Water Memorandum 91.15 in carrying out these four steps.

The responsibility for ensuring that appropriate procedures are correctly applied in processing sediment data is held by the Data Section Chief. During the time the sediment data are being processed for the year, field notes and work sheets for each site are maintained in the current folder. After the record has been completed, field notes and work sheets are maintained in the District backfiles.

\section{Sediment Laboratory}

A sediment laboratory is not operated in this District. Currently (January 2000) samples collected by the South Carolina District are processed by the Kentucky District Lab.

\section{Sediment Station Analysis}

A sediment station analysis is written for each sediment station operated by the District each water year. The sediment station analysis is a summary of the sediment activities at the station for a given year. The analysis describes the coverage of sampling, the types of samples and sampling, changes that might affect sediment transport or the record, and the methods and reasoning used to compute the record. Information included in the sediment station analysis is presented in a thorough manner, such that the checker and the reviewer can determine from the analysis the adequacy of the activities in defining the record and in accomplishing the objectives defined for the station (Office of Surface Water Memorandum 91.15). Elements included in each sediment station analysis are listed in Office of Surface Water Memorandum 91.15 along with descriptions of the elements and examples.

\section{Sediment Analysis Results}

The South Carolina District (excluding NAWQA) currently collects suspended-sediment samples at one partial-record station. Suspended-sediment concentration data are published in the Annual Data Report.

\section{Sediment Data Storage}

Hard copies of analyses and computations are archived in the District backfiles. Electronic files are maintained in the QWDATA (NWIS) data base. After the electronic file is reviewed for publication purposes, it is archived according to WRD policy.

\section{DATA-BASE MANAGEMENT}

Unit and daily values are flagged final by personnel checking the annual record for publication. Unit values from the LRGS (original DCP data) are downloaded to tape on a quarterly basis by the Computer Specialist. Backups of the ADAPS data base are completed on a daily basis by a phantom job than runs at 2300 hours. The daily values summary of the ADAPS data base is reviewed annually by the Data Section Chief or his designee to ensure that data are finalized and complete. The South Carolina District's basin characteristics file is maintained by the Data Section Chief or a designee. 


\section{PUBLICATION OF SURFACE-WATER DATA}

The act of Congress (Organic Act) that created the U.S. Geological Survey in 1879 established the Survey's obligation to make public the results of its investigations and research and to perform, on a continuing, systematic, and scientific basis, the investigation of the geologic structure, mineral resources and products of the National domain (U.S. Geological Survey, 1986, p. 4). Fulfilling this obligation includes the publication of surface-water data and the interpretive information derived from the analyses of surface-water data.

\section{Publication Policy}

The USGS and WRD have created specific policies pertaining to publication of data and interpretation of those data. All WRD personnel, including those of this District, are required to abide by those policies. A brief summary of goals, procedures, and policies are presented in U.S. Geological Survey (1986, p. 4-37).

All information obtained through investigations and observations by the staff of the USGS or by its contractors must be held confidential and not be disclosed to others until the information is made available to all, impartially and simultaneously, through Director-approved formal publication or other means of public release, except to the extent that such release is mandated by law (U.S. Geological Survey, 1986, p. 14). With the approval of the Director, hydrologic measurements resulting from observations and laboratory analyses, after they have been reviewed for accuracy by designated WRD personnel, have been excluded from the requirements to hold unpublished information confidential (U.S. Geological Survey, 1986, p. 15).

All interpretive writings in which the USGS has a proprietary interest, including abstracts, letters to the editor, and all writings that show the author's title and USGS affiliation, must be approved by the Director before release for publication. The objectives of the Director's review are to final-check the technical quality of the writing and to make certain that it meets USGS publication standards and is consistent with policies of the USGS and U.S. Department of the Interior. Director's approval ensures that (1) each publication or writing is impartial and objective, (2) has conclusions that do not compromise the USGS's official position, (3) does not take an unwarranted advocacy position, and (4) does not criticize or compete with other governmental agencies or the private sector (U.S Geological Survey, 1991, p. 10).

\section{Types of Publications}

Various types of book publications released by the USGS are available in which surface-water data and data analyses are presented. Publications of the formal series include the Professional Paper, Bulletin, Circular, Techniques of Water-Resources Investigations, Special Reports, and Selected Papers in the Hydrologic Sciences (U.S. Geological Survey, 1986, p. 42). Publications in the informal series include the Water-Resources Investigations Report, Open-File Report, and Administrative Report (U.S. Geological Survey, 1986, p. 52). Included in the Open-File Report series are data reports. Surface-water data collected by this District are published each year in a hydrologic data report that belongs to the annual series titled "U.S. Geological Survey Water-Data Reports." Factors considered by the District when deciding which form of publication should be utilized in presenting various types of information are presented in Green (1991, p. 14).

\section{Review Process}

Procedures for publication and requirements for manuscript review by WRD are summarized in U.S. Geological Survey (1991, p. 36-41). This District fulfills those requirements for review and approval of reports prior to printing and distribution. All reports written by USGS scientists in connection with their official duties 
must be approved by the originating Division and the Director. At least two technical reviews of each report are required by WRD (U.S. Geological Survey, 1991, p. 36). Competent and thorough editorial and technical review is the most certain way to improve and assure the high quality of the final report (Moore and others, 1990, p. 24). Principles of editorial review and responsibilities of reviewers and authors are presented in Moore and others (1990, p. 24-49). Open-file Reports are not required to receive editorial review, but are reviewed for policy and reproducibility (U.S. Geological Survey, 1991, p. 36).

It is the South Carolina District policy that all review copies of a published report are archived with other project information. The procedures for archiving these data are discussed in the "Archiving" section of this report.

The Data Chief is responsible for ensuring the quality of the Annual Data Report and has authority of approval for publication. Distribution of the Annual Data Report is achieved by maintaining a mailing list of cooperators and other individuals that return a request form from the previous years report.

\section{SAFETY}

Performing work activities in a manner that ensures the safety of personnel and others is of the highest priority for the USGS and the South Carolina District. Beyond the obvious negative impact unsafe conditions can have on personnel, such as accidents and personal injuries, they also can have a direct effect on the quality of surface-water data and data analysis. For example, errors may be made when an individual's attention to detail is compromised when dangerous conditions create distractions. So that personnel are aware of, and follow, established procedures and policies that promote all aspects of safety, the District communicates information and directives related to safety to all personnel by in-house training classes, memorandums, videotapes, and formal training. Specific policies and procedures related to safety can be found in the District Safety Plan and other material. It is the responsibility of each employee to inform the Safety Officer of any safety hazards that arise and to be thoroughly knowledgeable of District Safety policies.

An individual has been designated as Safety Officer by the District Chief. The Safety Officer's duties include the discussion of information pertaining to safety (particularly new WRD policies) and ensuring formal training courses for first aid, CPR, and defensive drivers training are completed as scheduled.

Personnel who have questions or concerns pertaining to safety, or who have suggestions for improving some aspects of safety, direct those questions, concerns, and suggestions to the Safety Officer.

\section{TRAINING}

Ensuring that personnel obtain knowledge of correct methods and procedures is a vital aspect of maintaining the quality of surface-water data and data analysis. By providing appropriate training to personnel, the District increases the quality of work and eliminates the source of many potential errors.

Training in the South Carolina District is provided by formal WRD training courses, local universities and technical colleges, and in-house workshops. Personnel in need of training should submit a Request for Training form to their immediate supervisor. If approved, the form is then forwarded to the Training Officer. In addition, supervisors should nominate personnel for training as deficiencies are determined, by consultation with the employee and Training Officer. In some cases, a mentor will be assigned to satisfy training needs. 


\section{SUMMARY}

Information included in this District Surface-Water Quality-Assurance Plan documents the policies and procedures of the South Carolina District that ensure high quality in the collection, processing, storage, analysis, and publication of surface-water data. Specific types of surface-water data discussed in this report include stage, streamflow, sediment, and basin characteristics. The roles and responsibilities of District personnel for carrying out these policies and procedures are presented, as are issues related to management of the computer data base and issues related to employee safety and training.

\section{SELECTED REFERENCES}

Arcement, G.J., and Schneider, V.R., 1989, Guide for selecting Manning's roughness coefficients for natural channels and flood plains: U.S. Geological Survey Water-Supply Paper 2339, 38 p.

Barnes, H.B, 1967, Roughness characteristics of natural channels: U.S. Geological Survey Water-Supply Paper 1849, 213 p.

Benson, M.A., and Dalrymple, Tate, 1967, General field and office procedures for indirect discharge measurements: U.S. Geological Survey Techniques of Water-Resources Investigations, book 3, chap. A1, 30 p.

Bodhaine, G.L., 1982, Measurement of peak discharge at culverts by indirect methods: U.S. Geological Survey Techniques of Water-Resources Investigations, book 3, chap. A3, 60 p.

Buchanan, T.J., and Somers, W.P., 1969, Discharge measurements at gaging stations: U.S. Geological Survey Techniques of Water-Resources Investigations, book 3, chap. A8, 65 p.

Carter, R.W., and Davidian, Jacob, 1968, General procedures for gaging streams: U.S. Geological Survey Techniques of Water-Resources Investigations, book 3, chap. A6, 13 p.

Dalrymple, Tate, and Benson, M.A., 1967, Measurement of peak discharge by the slope-area method: U.S. Geological Survey Techniques of Water-Resources Investigations, book 3, chap. A2, 12 p.

Davidian, Jacob, 1984, Computation of water-surface profiles in open channels: U.S. Geological Survey Techniques of Water-Resources Investigations, book 3, chap. A15, 48 p.

Edwards, T.K., and Glysson, G.D., 1988, Field methods for measurement of fluvial sediment: U.S. Geological Survey Open-File Report 86-531, 118 p.

Green, J.H., 1991, WRD project and report management guide: U.S. Geological Survey Open-File Report 91-224, 152 p.

Guy, H.P., 1969, Laboratory theory and methods for sediment analysis: U.S. Geological Survey Techniques of WaterResources Investigations, book 5, chap. C1, 58 p.

1970, Fluvial sediment concepts: U.S. Geological Survey Techniques of Water-Resources Investigations, book 3, chap. C1, 55 p.

Guy, H.P., and Norman, V.W., 1970, Field methods for measurement of fluvial sediment: U.S. Geological Survey Techniques of Water-Resources Investigations, book 3, chap. 2, 59 p.

Hubbard, E.F., 1992, Policy recommendations for management and retention of hydrologic data of the U.S. Geological Survey: U.S. Geological Survey Open-File Report 92-56, 32 p.

Kennedy, E.J., 1983, Computation of continuous records of streamflow: U.S. Geological Survey Techniques of WaterResources Investigations, book 3, chap. A13, 53 p.

1984, Discharge ratings at gaging stations: U.S. Geological Survey Techniques of Water-Resources Investigations, book 3, chap. A10, 59 p.

1990, Levels at streamflow gaging stations: U.S. Geological Survey Techniques of Water-Resources Investigations, book 3, chap. A19, 31 p. 
Kilpatrick, F.A., and Schneider, V.R., 1983, Use of flumes in measuring discharge: U.S. Geological Survey Techniques of Water-Resources Investigations, book 3, chap. A14, 46 p.

Knott, J.M., Glysson, G.D., Malo, B.A., and Schroder, L.J., 1993, Quality assurance plan for the collection and processing of sediment data by the U.S. Geological Survey, Water Resources Division: U.S. Geological Survey Open-File Report 92-499, $18 \mathrm{p}$.

Knott, J.M, Sholar, C.J., and Matthes, W.J., 1992, Quality assurance guidelines for the analysis of sediment concentration by the U.S. Geological Survey sediment laboratories: U.S. Geological Survey Open-File Report 92-33, 22 p.

Matthai, H.F., 1967, Measurement of peak discharge at width contractions by indirect methods: U.S. Geological Survey Techniques of Water-Resources Investigations, book 3, chap. A4, 44 p.

Moore, J.E, Aronson, D.A., Green, J.H., and Puente, Celso, 1990, Report planning, preparation, and review guide: U.S. Geological Survey Open-File Report 89-275, 81 p.

Novak, C.E., 1985, WRD data reports preparation guide: U.S. Geological Survey Techniques of Water-Resources Investigations, book 3, chap. C3, 66 p.

Porterfield, George, 1972, Computation of fluvial-sediment discharge: U.S. Geological Survey Techniques of WaterResources Investigations, book 3, chap. C3, 66 p.

Rantz, S.E., and others, 1982, Measurements and computation of streamflow, volumes 1 and 2: U.S. Geological Survey Water-Supply Paper 2175, 631 p.

Sauer, V.B., and Meyer, R.W., 1992, Determination of errors in individual discharge measurements: U.S. Geological Survey Open-File Report 92-144, 21 p.

Schroder, L.J., and Shampine, W.J., 1992, Guidelines for preparing a quality assurance plan for the district offices of the U.S. Geological Survey: U.S. Geological Survey Open-File Report 92-136, 14 p.

Shampine, W.J., Pope, L.M., and Koterba, M.T., 1992, Integrating quality assurance in project work plans of the U.S. Geological Survey: U.S. Geological Survey Open-File Report 92-162, 12 p.

Shearman, J.O., 1990, User's manual for WSPRO—A computer model for water surface profile computations: U.S. Federal Highway Administration Report, FHWA-IP-89-027, 187 p.

Smoot, G.F., and Novak, C.E., 1968, Calibration and maintenance of vertical-axis type current meters: U.S. Geological Survey Techniques of Water-Resources Investigations, book 8, chap. B2, 15 p.

U.S. Geological Survey, 1986, Water Resources Division publications guide; Volume I, Publications policy and text preparation (2d ed., revised by D.W. Alt and K.T. Iseri): U.S. Geological Survey Open-File Report 87-0205, 429 p. 1991, Suggestions to authors of the reports of the United States Geological Survey (7th ed., edited by W.R. Hansen): Washington, D.C., Government Printing Office, 289 p. 


\section{Appendix 1. Water Resources Division Memorandums Cited}

\begin{tabular}{|c|c|c|c|c|c|c|}
\hline \multirow{5}{*}{\multicolumn{2}{|c|}{$\begin{array}{l}\text { Office of Surface Water memorandums: } \\
\text { (across, in descending order) }\end{array}$}} & 99.06 & 93.12 & 93.11 & 93.07 & 93.01 \\
\hline & & 92.11 & 92.10 & 92.09 & 92.08 & 92.05 \\
\hline & & 92.04 & 91.15 & 91.09 & 90.10 & 90.08 \\
\hline & & 90.01 & 89.08 & 89.07 & 88.18 & 88.17 \\
\hline & & 88.07 & 87.05 & 85.17 & 84.05 & 83.07 \\
\hline \multicolumn{2}{|l|}{ Water Resources Division memorandums: } & 99.33 & 92.59 & 77.83 & 77.60 & 71.73 \\
\hline \multicolumn{2}{|c|}{ Water Resources Division technical memorandum: } & 95.19 & & & & \\
\hline Office of Water Quality memorandums: & 80.17 & 80.07 & 79.17 & 77.07 & 76.17 & 76.04 \\
\hline \multicolumn{4}{|c|}{ Memorandum from the Chief, Branch of Operational Support: } & \multicolumn{3}{|c|}{ May 7, 1993} \\
\hline
\end{tabular}




\section{PIBLD INSPECTION FORM FOR SURPACE-WATER REVIEWS (TWO PAGBS)}

Station No. station Name Office District

Reviewer Date

Station descriotion: Updated Location adequate? Equipment described? No. of RMs/BMs?

Comments :

Eield folders: Is there a current station description in the shelter? Log sheet? Rating curve? Rating table?

Other comments:

Chanoel/control conditions:

Measurement sites: Is the high-water site maintained?

Are Cables or bridges marked?

Comments

Shelter and well: Are weeds and brush cleared? Is the shelter clean? other comments: Are inside gages in good condition?

Equigment: What type recorders are in the gage?

Is there a rain gage? Are there solar cells? Line power?

Is there a DCP?

Are there high Other comments: low indicators on the float tape?

Bubble aages: Tank pressure psi. Feed pressure Bubble rate Bubbles/minute Does the record show stairstepping? Are there low points in the line? Orifice direction: Perpendicular to flow? Facing upstream? Other comments: Orifice stable? 


\section{FIBLD INSPECTION FORM FOR SURPACE-WATER REVIEWS (Continuation)}

Station No.

Outside gaces: Are there staff gages? Crest-stage gages (CSG)? Wire-weight gages? Are staff gages well maintained? Are holes in CSG in correct position? Other comments:

Gace readings: Outside Chk bar Et. ADR Dial ft. Wire wt ft. Tape index ft. Electric tape gage ft. Manometer dial other (describe) Comments :

Provigions for sediment samples (Describe any problem areas):

Safety: Is nitrogen tank adequately secured?

Is mercury spilled in the shelter?

Are bridge measurement conditions safe?

Is cable backstay tight?

No. of clips?

Are cable clips on properly?

Are cables at anchor clear of debris?

Are U-bars in good condition?

Is cable car in good condition?

Is there rust on the cables?

Handrails as needed?

other comments: 
REV.2 (10.9n

\author{
U.S GEOLOGICAL SURVEY
}

WATER RESOURCES DIVISION

SOUTH CAROLINA DISTRICT

\title{
GAGING STATION INSPECTION NOTES
}

STATION NUMBER:

STATION NAME:

PARTY:

DATE:

DCP W-NUMBER:

BDR I.D.

ENCODER I.D.

\section{GAGE READINGS}

\begin{tabular}{|c|c|c|}
\multicolumn{1}{c|}{ MAXIMUM: } & MONMUM: \\
\cline { 2 - 3 } & ON ARRIVAL & ON DEPARTURE \\
\hline TIME(EST) & & \\
\hline OG/TD/WWG & & \\
\hline TAPE GAGE & & \\
\hline INSIDE GAGE & & \\
\hline AUX.GAGE & & \\
\hline DCP/BDR & & \\
\hline BATTERY & & \\
\hline
\end{tabular}

REMARKS: 
station

SUMMARY OF LEVEL NOTES

Date

WIRB-WEIGHT GAGB

Check bar readings

Check bar elevations

INSIDE STAFE GAGE

Blevation of Party

No. gage read correct

\begin{tabular}{|l|l|l|l} 
Left by last levels & Start of these levels & Loft by these levels \\
\hline & & \\
\hline & & \\
\hline
\end{tabular}
equals ft on gage equals

ft by levels. Correction needed to make ft by levels after change.

OUTSIDE STAFF GAGE Elevation of ___t on gage equals gage read correct equals

TAPE GAGB evel: Gage changed by

ft by levels. Correction needed to make ft. Blevation of ft on gage

Elevation of water surface by (level ) Correction needed ta make tape read correct Tape polnter reads RBFERBNCE MARKS

Levele based on after change. ft. Elevation of $f t$ on gage

\begin{tabular}{l|l|l|l|l}
\hline \multicolumn{2}{c}{ Levelo based on } & \multicolumn{2}{c}{ condition } \\
R.M. & station Desc. Blevation & Blevation by last levels & Blevation by these lovels \\
\hline & & & \\
\hline & & & \\
\hline & & & \\
\hline
\end{tabular}




\section{Appendix 5. Example of Station Description}




\section{UNTTED STATES \\ DEPARTMENT OF THE INTERIOR \\ GEOLOCICAL SURVEY \\ WATER RESOURCES DIVISION}

\section{ADCP DISCHARGE, MEASUREMENT NOTES}

Sta. No.

Name

Dave

Pany

Width

Area

Vel.

G.H.

Discherge

APCP

Transducer Trequency

Beam

angle.

Depph of

\section{Software}

version

Firmware

version

diag lest

Transece data

\begin{tabular}{|c|c|c|c|c|c|c|}
\hline Time & G.H. & \begin{tabular}{|l|} 
Distence \\
2 Stan : \\
\end{tabular} & $\frac{10 \operatorname{ben} 2}{2 \operatorname{Stop} a}$ & Discharge & Configuration file & Raw dala file \\
\hline & & ${ }^{2}$ & & & & \\
\hline & & 2 & & & & \\
\hline & & T & & & & \\
\hline & & t & 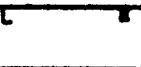 & & & \\
\hline & & $L^{2}$ & L & & & \\
\hline & & $\mu^{2}$ & & & & \\
\hline
\end{tabular}

Measurement rated: excellenh good, fair, poor, besed on the following criteris:

Fow

Crosesection

Bad ensembles

Coef. of Variation (CV $\left.=\sigma / Q^{\times 100}\right)$

Remarks 


\section{Appendix 7. Instructions for Completing Discharge Measurement Notes}

The following instructions are to be used by all personnel in computing Discharge Measurement Notes. Because all measurements are to be computed in the field, only item No. 3 will be done in the office. All others will be completed in the field.

1. Measurement No. - The next consecutive number in the sequence of measurements. This can be found in the field folder.

2. Comp. by - The initials of the person making the measurement.

3. Checked by - The initials of the person checking the measurement.

4. Sta. No. - The 8 or 9-digit, downstream order number of the stream.

5. Stream name - Complete stream name.

6. Date - The month, day, and year with the month spelled out. For example, February 21, 1979.

7. Party - The first two initials and last name of person(s) making the measurement.

8. Width - The exact stream width with no rounding off, including overflow channels. For example $10.5 \mathrm{ft}, 169 \mathrm{ft}$, $1,037 \mathrm{ft}$.

9. Area - Rounded to $\underline{3}$ significant figures. Use zeroes as necessary to give three places.

10. Vel. - Discharge divided by area. This figure will be carried out $\underline{2}$ places to right of the decimal.

11. G.H. - Mean gage height for the measurement. Always carried to hundredths. Gage-height should be weighted if change in stage during measurement exceeds 0.15 feet.

12. Disch. - Rounded to $\underline{3}$ significant figures. Use zeroes as necessary to give three places.

13. Method - The point method used in observing the velocities. These are primarily 0.6 or $0.2 / 0.8$ although surface velocities (S.V.) and 0.5 method are sometimes used. The predominant method will be listed first, then the secondary method. A secondary method should not be listed unless those sections constitute at least $10 \%$ of the total measure sections. For example, $0.2 / 0.8,0.6$ or $0.6,0.2 / 0.8$

14. No. secs. - Number of sections, including edges of water and estimates at piers.

15. G. H. Change - Change in G. H. during actual time the stream was being measured or the time from edge of water to edge of water. For example, $\underline{-0.02}$ in $\underline{0.92} \mathrm{hrs}$. Time to the nearest hundredth of an hour (min.(meas.) divided by 60 )

16. Susp. - The size weight used unless waded, in which case use "rod."

17. Method coef. - Not used.

18. Hor. angle coef. - The range of angles observed. For example, 0.70-0.99.

19. Susp. coef. - Not used.

20. Meter No. - Self-explanatory.

21. Type of meter - AA., L.V., pygmy.

22. Date rated - The date on the meter rating table.

23. Meter .... ft. - Distance the meter is above bottom of weight.

24. Spin "before" and "after" meas. - Actual time of spin test before and after measurement.

25. Wading, cable, etc. - Strike out all but pertinent information in first section, then add in distance from gage and other information regarding the measuring site. 
26. Check-bar, found - This is the elevation of the W.W.G. check bar at the initial inspection. Changed to - Reading the check bar was changed to and the time.

27. Correct - This is correct elevation of check bar as determined by last levels.

28. Levels obtained - Either yes or no.

29. Measurement rated - Delete all but the applicable rating. If measurement is rated less than "good," give explanation under "Remarks" section.

30. Cross-section - Description of the cross section.

31. Flow - Description of the flow pattern.

32. Weather - Description of the weather conditions.

33. Other - Additional comments concerning conditions during the measurement.

34. Air - Record in degrees $C$.

35. Gage - Note that gage was inspected and any problems found on arrival (use additional sheets as necessary).

36. Water - Record in degrees $C$.

37. Record removed - Yes or No.

38. Intake flushed - Yes or No.

39. Observer - In most instances there is no observer. If there is one and you talked with him, record any information regarding the station.

40. Control - Record type and condition of the control. If control is obstructed, make the discharge measurement BEFORE you clear the control.

41. Remarks - Any additional pertinent information not covered above.

42. G.H. of zero flow - Self-explanatory. 


\section{Appendix 8. Vehicle Equipment List}

\section{Mandatory Items}

Current meters, Price AA (2)/Std. rating tables

Headphones (2)

Stop Watches (2)

Tagline reel

A-Reel

Sounding weights (15c 30c 50c)

Spare hanger for reel

Weight pins (15c 30c 50c)

Tool Box

Steel tape (50 ft) and weight for tape down

Wading rod

Hip boots

Waders

Raincoat or rainsuit

Life jacket

Safety equipment for traffic

Flashlight

Stakes, nails, and flagging for high-water marks

Pygmy meter/Std. rating tables
Spare floats/counter weights

Spare locks (2640) and keys

Field folders

Copy of District Flood Plan

\section{Nonmandatory Items}

50' rope

Thermometer

Bucket

Bush axe/machete

Shovel

Batteries

Note forms:

Measurement sheets (single and double)

Miscellaneous note forms

Inspection forms (DCP)

Level notes

Clipboards

Pencils

Calculator

Spare tape gages/end hooks 
US GEOLOGICAL SURVEY CREST STAGE GAGE INSPECTION

Station Number:

Slation Name:

Party: Time Date

Measure all high water marks on all gages:

The crest gage is: UPSTR UPSTR UPSTR MIDDLE

Pin Elovalion

+ Pin-10-Mark Distance

- HWM Elevalion Quality of Mark Date of Mark The cresl gage is:

Pin Elevalion

+ Pin-10-Mark Dislance

- HWM Elevalion Quality of Mark Dale of Mark

Tapedowns or lapeups to water surface:

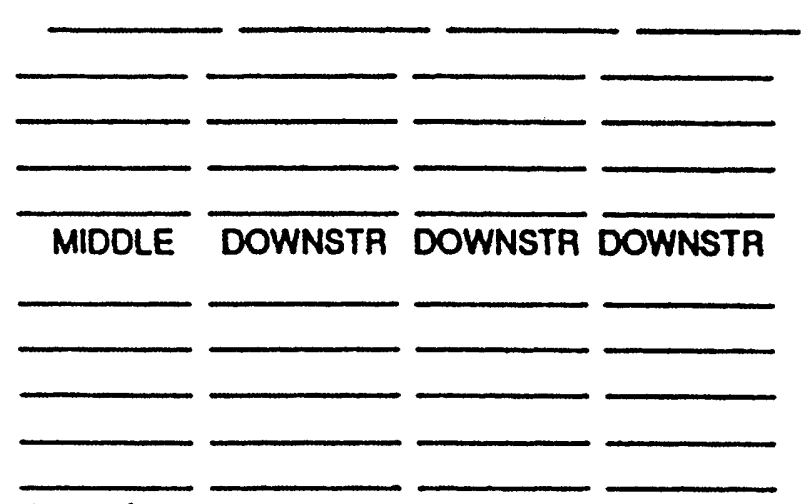

The lapedown point is:

TDP or Pin Elovalion

Tape Length

Tape Welght Length

Water Surface Elevation

Time

NOTE: GET WATER SURFACE AT DS TDP EVERY INSPECTIONI

Rubbed all cork ofl all sticks?

Marked and daled all HWM's on all sticks?

Bollom cap recharged?

Condition ol crest gages:

Recharged al lop?

Condition of downstream control:

Was water on any gage when the stick was removed?

IF SO, NOTE WHICH GAGE AND THE PRESENT STAGE AT GAGE.

For culvent:

(1) Plolled the HWM's on US vs DS slage graph?

DOES NOT FOLLOW THE TREND OF THE OTHER PLOTTED POINTS, CHECK

YOUR MEASUREMENTS AND FLAG HIGH WATER MARKS IF NECESSARYIII

(2) Barrels and culvert-to-US-gage area clean?

(3) Has mud or debris accumulation changed?

(4) IF SO, MEASURE AND SKETCH ON BACK OF THIS FORMIII

REMOVE DEBRIS OR STATE WHY NOT.

Remarks 


\section{Appendix 10. Data Processing Procedures}

Data processing (steps 1-10 below) will be completed during the 5-days following the completion of field work. A field trip is not complete until all data are processed and filed. The following procedures will be used to process data (use as a checklist, if necessary):

1. Discharge measurements go to the work-study or co-worker for checking.

2. Crest-stage gage and rain gage notes go to Tim Lanier.

3. Ground water data (primaries, plots, and inspections) are filed in the current folder.

4. Run primaries for all stations and annotate primaries with inspection and/or measurement information. Primaries are filed in chronological order in the current folder.

5. Run monthly plots of unit value data and file in chronological order in the current folder.

6. Pull unit-values tables for any days with bad values and then edit bad values.

7. Update current folder with discharge measurement information (plot measurement on work-curve and complete shift-computation sheet).

8. Update measurement file in ADAPS (shift and percentage difference may be omitted) and pull hard copy for current folder.

9. Field folders MUST contain the following information/documents:
A. Field Folder log sheet
B. Location map
C. Current station description
D. Current rating table and rating curve (daily discharge sites only). Copies of discharge measurements at various streamflows are recommended.

10. Current folders MUST contain the following information/documents:
A. Location map
B. Current station description (use this description as a work copy for any changes).
C. Current rating table, rating curve, and discharge measurement shift computation sheet (daily discharge sites only).
D. Level summary
E. Measurements and inspection in chronological order.
F. Up-to-date primary computations in chronological order.
G. Up-to-date unit value plots (by month) in chronological order. 


\section{Appendix 11. Instructions for Generating Final Daily Discharge Table}

\section{CHECKLIST FOR GENERATING DISCHARGE STATISTICS AND POPULATING "PUBLISHED” DD}

Set the final flag for GAGE HEIGHT for the correct year as follows:

1. SU-3 (set unit/daily values records flags)

2. Change OT to terminal

3. Change station number (if necessary) and select "GAGE HEIGHT" DD

4. Select option 1 (set DV flags to final) and enter WATER YEAR

5. Answer "yes" to "execute the control file now"

Set the final flag for DISCHARGE for the correct year using the above steps except the DD should be DISCHARGE not GAGE HEIGHT

Pull D. V. discharge card-image data as follows:

1. RT-1 (retrieve/write daily values data)

2. Make sure the water year (YR) is correct and $\langle\mathrm{cr}\rangle$

3. Enter the output file name (name it "CARDS")

4. Select " $D$ " (type $2+3$ cards)

5. Select " 3 " (specifies mean discharge)

6. Answer "Y" for final data only

7. Answer " $\mathrm{N}$ " for another retrieval

Update the "Discharge, published" DD by loading the card-image file:

1. IN-7 (process daily value card image data)

2. Enter filename (filename $=$ CARDS)

3. Select option 2 (add/replace)

4. Answer "Y" (flag as "final")

5. Select option 2 (flag as "already sent to Amdahl")

6. Answer "N" (do not "suppress roundings")

7. Select the "DISCHARGE, PUBLISHED" DD and the processing will begin

8. Answer "N" to "process more DV card files"

Update the instantaneous gage height and discharge for the "DISCHARGE, PUBLISHED" DD

If necessary update the period of record statistics:

1. DI-16 (edit daily value statistical summary)

2. Change the DD to "DISCHARGE, PUBLISHED" of necessary and 〈cr〉

3. Answer "Y" to "create the file"

4. Select option 2 (edit statistics)

5. Edit statistics as necessary (PW thru LR; LW= instantaneous min.)

6. Answer "Y" to "save changes"

7. Select option 4 (recompute statistics)

8. Answer "Y" to "do you really want to recompute"

9. Answer "Y" to "save changes"

10. Type "QU" to exit DV Table edit

Print two hard copies of final D.V. table w/stats (attach one to manuscript)

1. PR-9 (daily value statistical summary)

2. Tabling option should already be right $(\mathrm{ST}=\mathrm{Y}, \mathrm{AN}=\mathrm{N}$, etc.) so $\langle\mathrm{cr}>$

3. Change OT to printer if necessary and make two copies

4. Change the DD to "PUBLISHED DISCHARGE" if necessary

5. Answer "N" to "more tables"

6. Make sure that the right statistics have been computed/updated for current year and period of record. 


\section{Appendix 12. Checklist for Daily Discharge Records Computations}

\section{DAILY DISCHARGE COMPUTATION CHECKLIST}

Station number Station name Water year

Computed by Checked by Reviewed by

Complete/update level summary (notes must have instrument number and front sheet) Check ADR tapes/DCP inspection notes and complete G.H. record form (add UV from ADAPS) Plot unit gage height values and edit as necessary (delete periods of bad record)

Check primaries (rating \#, missing record, etc.)

Determine datum corrections and enter into ADAPS shift correction file

Check measurements for correct "rating" using the following guidelines:

"Good"- No sections $>10 \%$ total Q and mean velocity $>0.50 \mathrm{ft} / \mathrm{s}$ and no angles $<0.90$

"Fair" - 1-2 sections $>10 \%$ total Q or mean velocity $<0.50 \mathrm{ft} / \mathrm{s}$ or angles $<0.90$

"Poor"- > 3 sections $>10 \%$ total Q or mean velocity $<0.20 \mathrm{ft} / \mathrm{s}$ or angles $<0.80$

Update work curve (develop new rating, if necessary)

Complete measurement work sheet (percentage differences and shifts). Apply shifts using the measurement "rating" and plotting trends as a guideline. Enter shifts into ADAPS

Document estimated record (if necessary) and enter estimated DV's into ADAPS (write-protect) Pull final primary and annotate with documentation information

Pull final DV table (SUPPRESS STATISTICS) and verify accuracy of estimated record Update Measurement File with shift and percentage difference info and CHECK for accuracy Plot final hydrograph with measurements AND compare with nearby station (s)

Pull copy of Annual Summary and VERIFY max and min G.H./Q

Write station analysis (access by "a annualreport" then "dn analysis.XX" where XX is W.Y.)

Update manuscript (checker will attach copy of final DV table)

Update station description as necessary (use hardcopy in current folder)

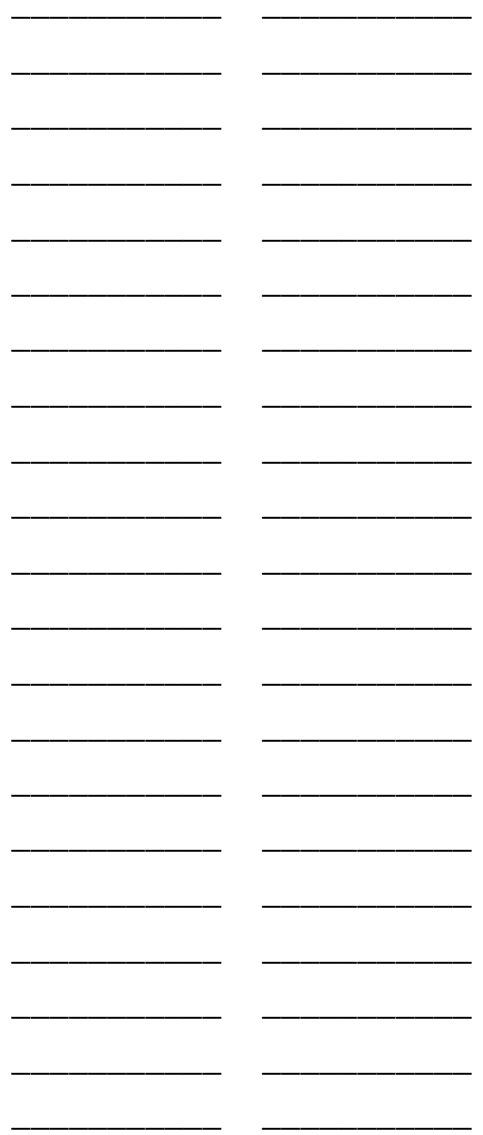

*****COMPUTER WILL STOP HERE. CHECKER WILL CONTINUE WITH REST OF CHECKLIST*****

The checker will populate the "Discharge, published" DD and generate the D.V. table with statistics after records computations have been checked and approved. Follow the procedures given in the "CHECKLIST FOR GENERATING DISCHARGE STATISTICS".

The final primary package will consist of the following: Station analysis ; DV table ; Annual hydrograph ; Annual Summary

Datum corrections summary ; Shift summary ; Shift analysis (optional) ; Discharge measurement summary (9-207) ; Documented primary sheets 


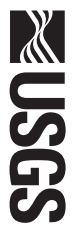

옹

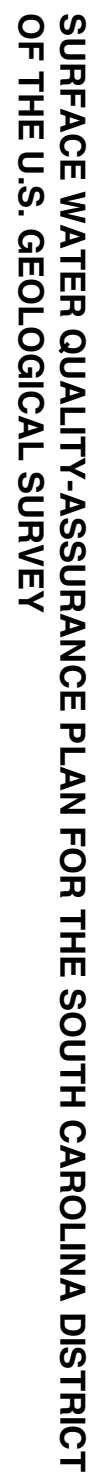

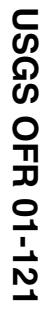

Printed on recycled paper 